\title{
PRODUCTION OF BIODIESEL FROM MIXED CASTOR SEED AND MICROALGAL OILS: CHARACTERIZATION AND OPTIMIZATION STUDIES
}

Dejene Beyene Lemma ( $\sim$ dejenebeyeneaau@gmail.com )

Jimma University Institute of Technology https://orcid.org/0000-0002-9843-5007

Mohammedsani Abdulkadir Abagisa

Matu Uninersity

Adisu Befekadu Kebede

Jimma University Institute of Technology

\section{Research}

Keywords: Biodiesel, Castor seed, CCD, Microalgae, Mixed oil, RSM, Transesterification

Posted Date: October 13th, 2020

DOl: https://doi.org/10.21203/rs.3.rs-66053/v3

License: (c) (i) This work is licensed under a Creative Commons Attribution 4.0 International License.

Read Full License 


\title{
Production of biodiesel from mixed castor seed and microalgal oils: characterization and optimization studies
}

${ }^{1}$ Dejene Beyene Lemma*, ${ }^{1}$ Mohammedsani Abdulkadir Abagisa, ${ }^{1}$ Adisu Befekadu Kebede ${ }^{1}$ Faculty of Civil and Environmental Engineering, Jimma University, Jimma Institute of Technology, 378, Ethiopia

Email: dejenebeyeneaau@gmail.com; mameakadir@gmail.com; adisu04@gmail.com

*Corresponding author

\begin{abstract}
In order to lower the high prices of individual feedstock, extend the life of a more limited feedstock and to improve the fuel properties of biodiesel it imperative to optimize process parameters for biodiesel derived from mixed feedstocks. Samples of castor seeds were collected from Jimma zone, southwest Ethiopia while sample of wet microalgal biomass was obtained from wastewater stabilization ponds using a $60 \mu \mathrm{m}$ filter screen. The castor seeds and microalgal biomass were sun-dried before further dried in an oven and ground to pastes. Oils were extracted from dry and milled castor seeds and microalgae pastes with a Soxhlet apparatus using methanol. The extracted oil was purified, mixed in 1:1 ratio and characterized before converted to biodiesel. A transesterification process designed using RSM based on CCD experimental design was used to optimize the production process parameters using alkaline catalyst. The Design Expert@ 12 software was used to analysis the experimental results. The effects of catalyst concentration, ethanol to oil molar ratio and reaction temperature on the yield of biodiesel were investigated using the experimental results. The optimum conditions for biodiesel production from mixed oil were a catalyst concentration of $1.23 \%$, alcohol to oil molar ratio of 5.94:1 and reaction temperature of 51.30 ${ }^{0} \mathrm{C}$. The yield of biodiesel under these conditions was $93.88 \%$. Experiment was conducted under the specified optimum conditions to validate the result predicted. The yield of biodiesel from the experiment was $93.36 \%$ which is very close to the value predicted by the model. The fatty acid composition of the biodiesel was analyzed using GC. The fuel properties of biodiesel were determined according to procedures outlined in ASTM D6751 and EN 14214 standards. The physicochemical properties fulfill both standards.
\end{abstract}

Keywords: Biodiesel, Castor seeds, microalgae, mixed oil, RSM, optimization 


\section{Introduction}

Nowadays, the global community heavily depends on the non-renewable and unsustainable petro-diesel fuel. A continued and increasing use of petrodiesel is exacerbating air pollution and intensifying global warming [1]. The use of petrodiesel produces primary air pollutants like nitrogen oxide $\left(\mathrm{NO}_{\mathrm{x}}\right)$ and sulfur oxide $\left(\mathrm{SO}_{\mathrm{x}}\right)$, carbon monoxide, carbon dioxide, hydrocarbons and suspended particulate matter which have a serious environmental and health impacts. In the atmosphere, $\mathrm{NO}_{\mathrm{x}}$ and hydrocarbons react to form tropospheric ozone that can damage vegetations, building materials and sensitive tissues. Several studies speculated that if population growth and utilization continue at the current rate, petro-diesel will become out of stock within the next few decades. Thus it's highly desirable to find an alternative fuel. One of the best available alternatives is the biodiesel. Biodiesel is a biodegradable, non-toxic, carbon neutral, has combustion properties similar to petro-diesel, made from local available feedstock and used in the current engine technology without significant modifications. The use of biodiesel can reduce emissions of $\mathrm{SO}_{\mathrm{x}}$ as it contains no appreciable sulfur [2].

\subsection{Feedstock for biodiesel production}

Different feedstocks have been used to produce biodiesel. Plant oils, animal fats and oils, algae and waste oils can be used as the feedstock. There are many edible and non-edible plant oils that can be used as feedstock of biodiesel. More than 350 oil bearing plants have been identified as a potential feedstock for biodiesel production. However, a sustainable and economical oil plants for biodiesel production must adapt to local conditions, high in oil contents, have suitable fatty acid compositions, low in agricultural inputs, produce mature seeds at uniform rates and grow in marginal lands unsuitable for food crop production. Oils from edible oilseed crops are being used as biodiesel feedstock in developed countries mainly to reduce greenhouse gas emissions and minimize reliance on non-renewable petrodiesel imports [3]. The use of edible oils as biodiesel feedstock cannot be sustainable in Ethiopia and other developing countries because devoting edible oils to biodiesel production compromises food security [2]. In addition, biodiesel made from edible oils cannot be economically competitive with petrodiesel. Also growing nonedible oil plants can mitigate climate change by reducing greenhouse gas emissions. Thus, industrial scale production of biodiesel at a reasonable cost needs the use of nonedible oils [3]. 
Ethiopia is home to diverse varieties of both edible and nonedible oil plants that have an ample potential for biodiesel production. Castor plant (Ricinus communis L.) is a flowering plant that belongs to Euphorbiaceae family [4]. The plant is native to Ethiopia though it is also widely distributed throughout the tropical, subtropical and warmer temperate regions [5]. Castor plant is resistant to both drought and pests and can grow very well on marginal lands unsuitable for food crop cultivation [6]. The average oil content of all castor seed varieties is $45-55 \%$ though the actual yield depends on climatic conditions and oil extraction methods. Nevertheless, castor oil is nonedible and toxic owing to the presence of a toxic protein. Castor oil is polar which accounts for its unique physical and chemical properties including high viscosity, specific gravity, boiling point and solubility in alcohol [4, 7]. Castor oil is a triglyceride containing ricinoleic acid (91-95\%), linoleic acid (4-5\%), oleic acid (24\%) and palmitic and stearic acids each 1-2\% [8].

A large variety of waste oils from households and restaurants, food and nonfood processing industries can be used as a cheap feedstock for biodiesel production. The use of waste oils can be an effective way to lower the cost of biodiesel feedstock. In addition, using waste oils as biodiesel feedstock can solve environmental problems associated with the disposal of such oils. However, waste oils contain high free fatty acids (FFAs), water and many other impurities that make biodiesel production more complicated and costly due to pre-processing $[9,10]$.

Animal fats and oils are also a potential feedstock for biodiesel production. The feedstock is less expensive than edible oils as it is a by-product rather than a primary product intended for biodiesel production. This makes animal fats and oils an attractive feedstock for biodiesel production [11]. Though high saturation makes biodiesel from animal fats and oils an excellent fuel with respect to energy content and cetane number, poor perform in cold climate is a great challenge. Furthermore, high saturation and water contents make alkaline transesterification a difficult process. Also it has been reported that the feedstock may not be plentiful enough to satisfy the current global fuel demands $[12,13]$.

Because of the limited supply, production of biodiesel from plant oils, waste oils and animal fats and oils may hinder its scaling up to satisfy the current global demands [14]. Thus, microalgae have been emerged as one of the most promising feedstock for biodiesel production. Fast growth rate, high oil content, ability to grow in areas unsuitable for food 
crop cultivation and low harvesting and transportation costs make microalgae an excellent biodiesel feedstock $[15,16]$. Also microalgae never compromise food security as they neither require a fertile farmland nor freshwater for cultivation. Microalgae yield more oils per hectare than other feedstocks. In addition, the use of microalgae as biodiesel feedstock can mitigate greenhouse gases emissions from power plants [22]. Microalgae for a large scale biodiesel production can be cultivated in an open or a closed reactor system [23].

Besides using plant oils, animal fats and oils, microalgal and waste oils, it is possible to use mixed feedstock to produce biodiesel. Blending feedstocks from different sources may extend the lifetime of a more expensive feedstock and improve the fuel properties of the resulting biodiesel as compared to those produced from individual feedstock [11]. Studies have been conducted to produce biodiesel from mixed canola, palm, soybean and sunflower oils [19], soybean and rapeseed oils [20], mahua and simarouba oils [21], palm, rapeseed and soybean oils [17], jatropha, palm and cottonseed oils [22], Jatropha curcas and Ceiba pentandra oils [23]. To the best of our knowledge, no study pertaining to the production, characterization and optimization of biodiesel from mixed castor and microalgal oils have been conducted.

\subsection{The biodiesel production process}

Due to high viscosity and poor ignition quality, the direct use of triglycerides (crude oils) is highly restricted. A variety of strategies including dilution, micro-emulsification, pyrolysis and transesterification have been used to solve these problems of crude oils. Transesterification can be catalyzed by alkali catalysts (e.g., $\mathrm{NaOH}, \mathrm{KOH}$ and their corresponding alkoxides), acid catalysts (e.g., $\mathrm{H}_{2} \mathrm{SO}_{4}, \mathrm{BF}_{3}, \mathrm{H}_{3} \mathrm{PO}_{4}$ and $\mathrm{HCl}$ ) or enzyme catalysts (e.g., lipases). Catalyzed transesterification reactions can be accomplished as onestep (basic or acidic) or two-step (acidic/basic) processes depending on the FFA contents of the feedstock. Based on the solubility of the catalyst in the reaction mixture, transesterification can be catalyzed by homogeneous or heterogeneous catalysts [3].

Homogenous alkali catalyzed transesterification is much faster, less expensive and more complete than the corresponding acid-catalyzed reaction [11]. According to Srivastava and Prasad [24], alkaline catalyzed transesterification is about 4,000 times faster than the corresponding acid catalyzed reaction. However, alkali catalyzed transesterification is very sensitive to water and FFA contents of the feedstock. Under alkaline conditions the presence 
of excess water may trigger soap formation. If present in sufficient amount FFAs react with alkali catalysts to produce soaps and water [11]. Saponification not only increases the cost of biodiesel production by consuming more catalysts but also the produced soap makes the purification of biodiesel a more difficult process. Homogenous acid-catalyzed transesterification is insensitive to FFA contents as they catalyze both esterification and transesterification reactions simultaneously. However, the reaction is slower, corrosive to equipment, low in catalyst activity, occurs at higher temperatures and pressure and requires longer time and a higher alcohol to oil molar ratio to achieve a significant yield of biodiesel. Homogeneous enzyme catalyzed transesterification is carried out in non-aqueous environments. Enzyme-catalyzed transesterification generates no by-products, produce high yield under mild conditions, insensitive to FFA and water contents of the feedstock, catalysis both transesterification and esterification reactions simultaneously and product separation and catalyst recovery are too easy. However, enzyme catalyzed transesterification requires a longer reaction time than the corresponding alkali and acid catalyzed transesterifications [11]. Furthermore, high costs and deactivation pertaining to impurities are the major hindrance to the use of this catalyst. Biodiesel can also be produced via non-catalytic supercritical fluid transesterification processes. The method is less expensive and produces high yield as both transesterification and esterification reactions occur simultaneously in a single step. Short chains anhydrous alcohols such as methanol, ethanol, propanol, butanol and amyl alcohols are commonly used to produce biodiesel. However, ethanol and methanol are the most frequently used alcohols mainly due to their lower cost, better yields, fast reaction time and suitable physical and chemical properties [25].

\subsection{Main factors affecting the yield of biodiesel}

The quality of feedstock largely determines the type of catalyst or process used to produce biodiesel of good quality [11]. Alcohol to oil molar ratio, catalyst concentration, reaction time and temperature, mixing speed, FFA and water contents of feedstock are the main factors that influence the yield of biodiesel [3].

Studies show that alcohol to oil molar ratio is the main factor that influences the yield of biodiesel. Stoichiometrically transesterification requires 3 moles of alcohol and 1 mole of triglyceride to yield 3 moles of biodiesel and 1 mole of glycerol [6, 20]. However, an excess alcohol must be used to shift the equilibrium to the right. Rising alcohol to oil molar ratio 
beyond 3:1 increases the yield of biodiesel until optimum point is reached. This is because a higher ratio can result in a greater ester conversion within a reasonable reaction time [24]. However, increasing the ratio beyond the optimum increases the cost for alcohol recovery from the reaction medium. The molar ratio also depends on the type of catalyst and most studies show that the optimal ratio for alkali catalysts is $6: 1$. Feedstock containing a higher percent of FFA, molar ratio as high as 15:1 may be used for acid-catalyzed transesterification. Catalyst concentration is another factor that influences the yield of biodiesel. At low catalyst concentration the low conversion rate of triglyceride can lead to low yield because insufficient catalysts result in incomplete conversion [26]. The yield usually reaches an optimal level at catalyst concentration of $1.5 \%$ and then decreases with further increase because excess catalyst causes more oil to form more soap. Thus, further increase in catalyst concentration encores additional costs associated with catalyst removal from the reaction medium without increasing the yield [24]. If the feedstock contains a significant amount of FFAs ( $\geq 3 \%$ ), homogenous alkali catalysts will not be effective as the excess catalyst react with the FFA to form soap and water [11,26]. For an optimal yield using a homogenous alkali catalyst, the FFA content of the feedstock must be $<0.05 \%$ [1]. For feedstock containing FFAs $\geq 1 \%$, alkali catalyzed transesterification must be preceded with an acid pretreatment. Types of catalyst also affect the transesterification and thus the yield of biodiesel. Sodium methoxide is more effective than $\mathrm{NaOH}$ because mixing $\mathrm{NaOH}$ and alcohol forms water, which affects the yield [11]. The oils, catalyst and alcohol used in alkali catalyzed transesterification must be anhydrous i.e. water content must $<0.05 \%$ in order to prevent the loss of biodiesel to soap formation [16].

Temperature also influences the rate of transesterification and yield of biodiesel [26]. A higher temperature can lower the viscosities, increases reaction rate and shortens reaction time but increasing reaction temperature beyond the optimal lowers the yield due to accelerated saponification reaction. In order to avoid loss of alcohol via vaporization, the reaction temperature must be less than the boiling point of the alcohol used for the transesterification $[1,10]$.

According to Freedman et al. [27] the conversion rate of oils increases with increase in reaction time. At the start, the reaction is slow because mixing and dispersion of alcohol with the oil need time and then it proceeds very fast. Once the yield reaches a maximum, a further 
increase in reaction time will not increase the yield because reaction time beyond optimum reverses transesterification reaction and more oils are used to produce soaps [26]. Alkali catalyzed transesterification reactions basically complete within $1 \mathrm{~h} \mathrm{[11].}$

\section{Materials and methods}

\subsection{Sample collection and preparation}

Wet microalgal biomass was collected from wastewater stabilization ponds at Jimma Institute of Technology, southwest Ethiopia, using $60 \mu \mathrm{m}$ filter screen and concentrated by centrifugation. The biomass was dried using a freeze drier and then milled to a paste using a mortar and pestle. The castor seeds were collected from Dedo district, Jimma zone and undergone various preparation steps including manual removal of foreign materials and seed shells, drying at $105{ }^{\circ} \mathrm{C}$ for $6 \mathrm{~h}$ and grinding to powder. The sun dried castor seeds and microalgal biomass were re-weighed to determine moisture content using Eq. (1):

MC, $\%=\frac{\text { Weght before drying }- \text { weght after drying }}{\text { Weght before drying }} \times 100$

All experiments were conducted in triplicate using analytical grade reagent chemicals and solvents. N-hexane (99\%), methanol (99\% purity), ethanol (99.5\% purity), KOH (95\% purity), anhydrous $\mathrm{NaOH}$ (98\% purity), $\mathrm{H}_{3} \mathrm{PO}_{4}$ (98\% purity), $\mathrm{HCl}$ (98\% purity), $\mathrm{H}_{2} \mathrm{SO}_{4}$ (98\% purity), anhydrous KI (98\% purity), phenolphthalein indicator, starch solution, chloroform, Hanus solution, anhydrous $\mathrm{Na}_{2} \mathrm{SO}_{3}$ and sodium thiosulfate were chemicals used to conduct the study.

\subsection{Oil extraction and purification}

The microalgal and castor seed pastes were used for oil extraction using methanol as a solvent. The castor seed paste was weighed and inserted into the center of extractor. The Soxhlet (Malad west, Mumbai, India) was heated to $60{ }^{\circ} \mathrm{C}$ and oil extraction was carried out for $1 \mathrm{~h}$. At the end of extraction time the castor seed paste was removed from Soxhlet, dried at $105{ }^{\circ} \mathrm{C}$, cooled and reweighed to determine the amount extracted oil. The oil content of both microalgae and castor seeds was determined using Eq. (2):

Oil content, $\%=\frac{\text { Weight of oil obtained }}{\text { Weight of sample used }} \times 100$

The extracted oil was filtered through a sieve and heated to $120{ }^{\circ} \mathrm{C}$ for $30 \mathrm{~min}$ to remove water and residual solvents. Then it was transferred to a separator funnel where it was separated into oil and heavy sludge (Fig. 3). The sludge which might contain phosphatides, 
pigments and other impurities was discarded. The oil was then washed repeatedly with warm distilled water until the washing water becomes neutral and as clear as it was before. A 0.50 $\mathrm{N} \mathrm{NaOH}$ was used to neutralize the FFA in the oil. Accordingly $0.86 \mathrm{~g}$ of $\mathrm{NaOH}$ was added per $100 \mathrm{ml}$ of oil at $70{ }^{\circ} \mathrm{C}$ and stirred at $200 \mathrm{rpm}$ for $1 \mathrm{~h}$. To separate solid materials the mixture was centrifuged at $800 \mathrm{rpm}$ for $20 \mathrm{~min}$. Then the oil was washed with distilled water to remove trace $\mathrm{NaOH}$. Finally, the oil was dried at $105{ }^{\circ} \mathrm{C}$ for $1 \mathrm{~h}$ to remove any water remaining.

\subsection{Physicochemical characteristics of mixed oil and biodiesel}

Before converting the oil to biodiesel via alkali catalyzed transesterification it was very important to characterize the oil to know the amount of pre-treatment needed. Properties such as moisture content, saponification value, acid value, kinematic viscosity at $40{ }^{\circ} \mathrm{C}$, specific gravity, density at $20{ }^{\circ} \mathrm{C}$, free fatty acid value, fatty acid composition and ash content were determined to ensure the appropriateness oil for alkali catalyzed transesterification. On the other hand biodiesel produced from the mixed oil undergone different laboratory tests to determine its fuel properties and qualities. The results were compared with European Union Biodiesel Quality (EN14214) and American Society for Testing and Materials (ASTM D6751) standards.

\subsubsection{Moisture content of the mixed oil and biodiesel}

Before transesterification, knowing moisture content of mixed oil was necessary because high water content facilitates side reactions [1]. Water content in excess of $0.050 \%$ can lower yield of biodiesel through hydrolysis of FFA and facilitating transesterification reaction to form soap. The produced soap also makes purification of biodiesel a difficult process. A higher water contents urges the use of acid catalysts [11]. In this study, the moisture content of mixed oil and biodiesel was determined using the oven drying method. The pre-weighed mixed oil and biodiesel samples were dried at $105{ }^{\circ} \mathrm{C}$ for $1 \mathrm{~h}$. The dried samples were reweighed and the moisture content of each was determined using Eq. (3):

$\mathrm{MC}=\frac{\text { Weight before drying }- \text { weght after drying }}{\text { Weght before drying }} \times 100 \%$

\subsubsection{Acid and free fatty acid values of mixed oil and biodiesel}

Acid value is used to quantify the amount of acid present in a sample of oil and biodiesel [1]. It is the quantity of a base (in $\mathrm{mg}$ of $\mathrm{KOH}$ ) required to neutralize acids present in $1 \mathrm{~g}$ of 
sample. Acid value of a feedstock has a significant effect on the transesterification reactions if an alkali catalyst is to be used [28]. Ethanol was added to the mixed oil sample and the mixture was boiled using a temperature controlled water bath. After cooling, 2 drops of phenolphthalein indicator was added to the mixture and then titrated with $0.10 \mathrm{~N} \mathrm{KOH}$ (Fig. 4). The mixture was washed with a distilled water to remove trace $\mathrm{KOH}$ and produced soap. The acid value of the oil was estimated using Eq. (4):

$\mathrm{AV}(\%)=\frac{\mathrm{C} \times \mathrm{V} \times 56.10}{\text { Weight of oil sample (g) }} \times 100$

Where $\mathrm{V}$ is volume of $\mathrm{KOH}$ used for titration and 56.10 is molecular weight of $\mathrm{KOH}$

The free fatty acid value of mixed oil and biodiesel is half of the corresponding acid value. The free fatty acid value was calculated using Eq. (5):

FFA $(\%)=\frac{\mathrm{AV}}{2}$

\subsubsection{Saponification value of mixed oil and biodiesel}

Saponification value is the amount of alkali catalyst $(\mathrm{NaOH}$ or $\mathrm{KOH})$ required to saponify $1 \mathrm{~g}$ of triglyceride under specific conditions. In this study, $2 \mathrm{~g}$ mixed oil was added to a conical flask containing $0.50 \mathrm{~mol} \mathrm{~L}^{-1} \mathrm{KOH}$ solution in anhydrous ethanol and heated to $70{ }^{\circ} \mathrm{C}$ for $30 \mathrm{~min}$. After cooling, a few drops of phenophtaline indicator were added to the mixture. The excess $\mathrm{KOH}$ was titrated against $0.50 \mathrm{~mol} \mathrm{~L}^{-1} \mathrm{HCl}$ using phenolphthalein indicator until the endpoint was reached and the volume of $\mathrm{HCl}$ needed to bring color change was recorded. A blank (without mixed oil) was saponified by the same procedure. The saponification value of the mixed oil was determined using Eq. (6):

$\mathrm{SV}=\frac{\left(B_{1}-B_{2}\right) \times \mathrm{C} \times 56.10}{\mathrm{M}(\mathrm{g})}$

Where $\mathrm{SV}$ is saponification value, $\mathrm{B}_{1}$ and $\mathrm{B}_{2}$ are the volumes of $\mathrm{HCl}$ used for blank fatty acid and oil mixture titrations respectively, $\mathrm{C}$ is the concentration of $\mathrm{HCl}\left(\mathrm{mol} \mathrm{L}^{-1}\right), \mathrm{M}$ is weight of oil and 56.10 is molecular weight of $\mathrm{KOH}$. The same procedure was used to determine the $\mathrm{SV}$ of biodiesel.

\subsubsection{Density of the mixed oil and biodiesel}

The specific gravity of the mixed oil was determined by taking the ratio of the mass of 50 $\mathrm{ml}$ mixed oil at $20{ }^{\circ} \mathrm{C}$ to the mass of an equal volume of water at the same temperature according to Eq. (7): 
$S_{g}=\frac{\mathrm{M}_{o} \text { at } 20^{\circ} \mathrm{C}}{\mathrm{M}_{w} \text { at } 20^{\circ} \mathrm{C}}$

Where $\mathrm{Sg}$ is specific gravity, $\mathrm{M}_{\mathrm{o}}$ is mass of $50 \mathrm{ml}$ of oil at $20{ }^{0} \mathrm{C}$ and $\mathrm{M}_{\mathrm{w}}$ is mass of $50 \mathrm{ml}$ of water at $20{ }^{0} \mathrm{C}$. The density of mixed oil was determined by multiplying specific gravity of mixed oil by density of water $\left(1000 \mathrm{~kg} \mathrm{~m}^{-3}\right)$. On the other hand, the density of the biodiesel sample at $15{ }^{\circ} \mathrm{C}$ was determined using a hydrometer. $100 \mathrm{ml}$ biodiesel sample was heated to $15{ }^{0} \mathrm{C}$ and filled into graduate cylinder. The hydrometer was inserted into the cylinder to measure its density. Reading was taken after the hydrometer becomes stabilized.

\subsubsection{Kinematic viscosity of mixed oil and biodiesel}

A digital Vibro viscometer (SV-10, Australia) was used to determine the viscosity of the mixed oil. The oil sample filled in the viscometer cup was kept in a water bath at $40{ }^{0} \mathrm{C}$ for $30 \mathrm{~min}$. The viscometer tip was inserted into the viscometer cup containing the mixed oil and reading was taken for a fixed volume. The reading of the viscometer is dynamic viscosity corrected to kinematic viscosity according to Eq. (8):

Kinematic viscosity $=\frac{\text { Dynamic viscosity }}{\text { Density of sample }}$

The kinematic viscosity was determined by determining the flow time for a volume of biodiesel to pass between two marked points. From the flow time (seconds), kinematic viscosity (in centistokes) was calculated using Eq. (9):

Kinematic viscosity $=$ C.t

Where $\mathrm{C}$ is the calibration constant for the instrument specified by manufacturer $(0.040350$ $\mathrm{mm}^{2} \mathrm{~s}^{-2}$ at $40^{\circ} \mathrm{C}$ ) and $\mathrm{t}$ is time required to pass between two marked points (in seconds). All measurements were carried in triplicate and only the average value was used in the final report [29].

\subsubsection{Iodine value of mixed oil and biodiesel}

Iodine value (IV) specifies the amount of iodine (g) consumed by $100 \mathrm{~g}$ of a biodiesel sample. In this study, IV was determined by placing $0.10 \mathrm{~g}$ biodiesel sample in an Erlenmeyer flask, adding $10 \mathrm{ml}$ of anhydrous chloroform followed by addition of $30 \mathrm{ml}$ of Hanus solution (Fig. 5. The entire content was then titrated against $0.140 \mathrm{M} \mathrm{Na} 2 \mathrm{~S}_{2} \mathrm{O}_{3}$ until the solution turned light yellow. After adding $2 \mathrm{ml}$ of $1 \%$ starch solution, titration was 
continued until a blue colour disappears. The blank titration was carried out without biodiesel sample. The IV was determined using Eq. (10):

$\mathrm{IV}=\frac{\left(B_{2}-R_{2}\right) \times N \times 12.69}{M(g)}$

Where IV is iodine value ( $\mathrm{g} \mathrm{I}_{2}$ per $100 \mathrm{~g}$ biodiesel), M is mass of biodiesel used ( $\mathrm{g}$ ), $\mathrm{N}$ is normality of $\mathrm{Na}_{2} \mathrm{~S}_{2} \mathrm{O}_{3}$ and $\mathrm{B}_{2}$ and $\mathrm{R}_{2}$ are the volume of $\mathrm{Na}_{2} \mathrm{~S}_{2} \mathrm{O}_{3}$ used for blank and sample titration respectively. The same procedure was used to determine iodine value of the mixed oil.

\subsubsection{Cetane number of biodiesel}

$\mathrm{CN}$ of the biodiesel was estimated using the results of SV and IV according to Eq. (11).

$\mathrm{CN}=46.3+\frac{5458}{\mathrm{SV}}-0.225 * \mathrm{IV}$

Where $\mathrm{CN}$ is cetane number, $\mathrm{SV}$ is saponification value and IV is iodine value

\subsubsection{Heating value of mixed oil and biodiesel}

Numerous mathematical models have been formulated to estimate the heating value of vegetable oils and biodiesel synthesized from them based on physical or chemical composition data, proximate or ultimate and structural analyses. In this study, an empirical formula suggested by Demirbas et al. [30] was used to estimate the heating value of the mixed oil and biodiesel as a function of IV and SV using Eq. (12):

$\mathrm{HHV}\left(\mathrm{MJ} \mathrm{kg}^{-1}\right)=49.43-[(0.041 \times \mathrm{SV})+(0.015 \mathrm{xIV})]$

\subsubsection{Flash point of biodiesel}

Pensky-Martens closed cup tester (FP-261, Germany) was used to measure the flash point of biodiesel sample. The cup was filled with biodiesel sample, heated with an external heater while being stirred. The stirrer was stopped periodically and the flame pivoted down to check if the biodiesel vapor ignites. The temperature at which a small flash observed was recorded as observed flash point of the biodiesel and corrected to atmospheric pressure $(760 \mathrm{mmHg})$ by applying the correction factor using Eq. (13):

$\mathrm{FP}($ corrected $)=\mathrm{T}+0.033(760-\mathrm{P})$

Where FP is flash point; $\mathrm{T}$ is observed temperature $\left({ }^{\circ} \mathrm{C}\right) ; \mathrm{P}$ is atmospheric pressure $(\mathrm{mmHg})$ prevailing at the time of test. 


\subsubsection{Ash content of mixed oil and biodiesel}

Furnace was used to determine the ash content of the oil. A cup containing $20 \mathrm{~g}$ oil was placed in a furnace for $4 \mathrm{~h}$ which was set at a temperature of $550{ }^{\circ} \mathrm{C}$. After burning the residue remaining was weighted and ash content was determined using Eq. (14):

$\mathrm{AC}=\frac{\mathrm{M}_{2}}{\mathrm{M}_{1}} \times 100 \%$

Where $\mathrm{M}_{1}$ is mass of oil before burning $(\mathrm{g}) ; \mathrm{M}_{2}$ is mass of oil after burning $(\mathrm{g})$.

\subsubsection{Fatty acid composition of mixed oil and ethyl ester composition of biodiesel}

Fatty acid composition of mixed oil and biodiesel was identified by GC method. Into a flask, a sample of mixed oil and n-hexane were added and shaken and stands idle for $1 \mathrm{~min}$. An anhydrous $\mathrm{Na}_{2} \mathrm{SO}_{3}$ was used to dry the solution. After shaking, the solution was let stand idle for 5 min until sedimentation occurs. The solution was analyzed using GC (Shimadzu, Tokyo, Japan) equipped with a flame ionization detector with a Supelcowax10 capillary column $(30 \mathrm{~mm} \times 0.25 \mathrm{~mm} \times 0.25 \mu \mathrm{m})$. The injector temperature was set at $250{ }^{\circ} \mathrm{C}$. The column temperature was programmed to increase from 50 to $250{ }^{\circ} \mathrm{C}$ at $4{ }^{\circ} \mathrm{C} \mathrm{min}{ }^{-1}$. The sample injection volume was $1 \mu \mathrm{L}$ with a split ratio of 1:20. The carrier gas used was $\mathrm{N}_{2}$ at a flow rate of $45 \mathrm{ml} \mathrm{min}^{-1}$, air and $\mathrm{H}_{2}$ flow rates were 30 and $300 \mathrm{ml} \mathrm{min}^{-1}$ respectively. Standard fatty acids, obtained from local vendor were injected to GC and identification of individual fatty acids was carried out by comparing the retention times of fatty acid samples with that of the reference. The percentage fatty acid compositions were obtained from their peak areas.

\subsection{Transesterification of the mixed oil under various conditions}

A mixture of castor and microalgal oil (1:1 ratio) was added to a three necked round bottom flask preheated to $60^{\circ} \mathrm{C}$ (Fig. 6). The reactor was submerged in a water bath placed on a plate with magnetic stirrer. The catalyst-alcohol solution was prepared freshly and added to the preheated reactor containing mixed oil under constant mixing speed (kept at $500 \mathrm{rpm}$ for all experimental runs). The experiments were carried out under varying conditions: reaction temperatures $\left(25-75^{\circ} \mathrm{C}\right.$, catalyst concentrations $(0.5-1.5 \%)$ and ethanol to oil molar ratios (3-12) to find out the optimum conditions. Finally the fatty acid ethyl esters (biodiesel) and glycerol mixture was allowed to separate gravitationally in a separator funnel into two distinct layers. The two layers were separated by draining the glycerol layer from the 
biodiesel. Once the reaction was complete, excess ethanol was evaporated using a rotaryevaporator. Then the product was filtered and analyzed to determine percent yield of biodiesel using Eq. (15):

Biodiesel yield $=\frac{\text { Wt of Biodiesel obtained }}{\text { Wt of oil used }} \times 100 \%$

\subsection{Purification of the produced biodiesel}

The crude biodiesel may contain many impurities including soap, water, glycerides, excess catalyst and unreacted alcohol. To comply with quality standards, impurities should be reduced to acceptable level. Impurities are detrimental to the stability of biodiesel, storage tanks and combustion systems [26]. In this study, the biodiesel was purified by washing with hot distilled water at $60{ }^{\circ} \mathrm{C}$ (Fig. 5) until the washing water achieved a neutral pH. Any remaining moisture was removed by drying it at $80{ }^{\circ} \mathrm{C}$ under vacuum rotary evaporator and passing it over anhydrous $\mathrm{Na}_{2} \mathrm{SO}_{3}[8]$.

\subsection{Design of experiment}

The conversion efficiency of feedstock to biodiesel depends on transesterification process variables. In the classical experiments, optimization is usually carried out by varying one variable while keeping all others constant which is not only time consuming and costly but also requires a large number of experiments [8]. Response surface methodology (RSM) is an effective statistical technique to design experiment, investigate the effects of individual factors and interactions between them [3]. In this study, central composite design (CCD) of RSM was used to evaluate the effects of individual variables and interaction between them. Experiments were conducted according to a $2^{\mathrm{n}}$ complete factorial for the three independent variables which gave a total of 17 experimental runs $\left(2^{n}+2 n+C P\right)$ where $n$ is the number of independent variables studied and $\mathrm{CP}$ is the number of central point. Each factor varied over five levels (Table 3). Eight factorial $\left(2^{\mathrm{n}}\right)$ and six axial experimental runs (2n) were carried out with three extra replications at the $\mathrm{CP}$ to evaluate the pure error [8]. The distance of axial points from the $\mathrm{CP}$ was calculated using Eq. (16)

$\pm \alpha=\sqrt[\frac{1}{4}]{2^{n}}$

Where $\mathrm{n}$ is the number of independent variables. Accordingly the lowest and highest levels were -1.68 and +1.68 respectively. The axial points were located at $( \pm \alpha, 0,0),(0, \pm \alpha, 0)$ and $(0,0, \pm \alpha)$ for the three independent variables (Table 1$)$. 
Transesterification of mixed oil was carried out at various catalytic concentrations $(0.50 \leq \mathrm{A}$ $\leq 1.5 \%)$, alcohol to oil molar ratios $(3: 1 \leq \mathrm{B} \leq 12: 1)$ and reaction temperatures $\left(25^{\circ} \mathrm{C} \leq \mathrm{C} \leq\right.$ $75^{\circ} \mathrm{C}$ ). The mixing speed and reaction time were set at optimum points for all experimental runs, ranges and levels based on previous studies [3, 8]. Levels of independent variables were selected based on the operating limit of transesterification process and literature data [13]. The highest reaction temperature level $\left(75^{\circ} \mathrm{C}\right)$ was chosen just below the boiling point of ethanol $\left(78^{\circ} \mathrm{C}\right)$ whereas the lowest level chosen was room temperature $\left(25^{\circ} \mathrm{C}\right)$. The highest level $(1.5 \%)$ and lowest level $(0.50 \%)$ of catalyst concentrations were chosen based on literature data. The lowest level of ethanol to oil molar ratio (3:1) was chosen based on the minimum stoichiometric amount required for the transesterification reaction whereas the highest level (12:1) was chosen based on previous studies [32]. The catalyst concentration of $1.0 \mathrm{w} / \mathrm{w} \%$, ethanol to oil molar ratio of 7.5:1 and reaction temperature of $50{ }^{\circ} \mathrm{C}$ was selected at $\mathrm{CP}$ for the experimental design.

\subsection{Statistical analysis}

Experimental data were analyzed using the quadratic model to establish the relationship between biodiesel yield and independent variables. The complete model equation describes the contributions of the various variables, significance of the different levels of variables and optimum conditions [8]. The relationship between variables at the center and interactions of the coded variables Xi on the yield of biodiesel is expressed using Eq. (17):

$Z=\beta_{0}+\sum_{i=1}^{n} \beta_{i} X_{i}+\sum_{i=1}^{n} \beta_{i i} x X_{i}^{2}+\sum_{i=1}^{n} \sum_{j<i}^{n} \beta_{i j} x X_{i j}$

Where $\mathrm{Z}$ is biodiesel yield (\%); $\beta \mathrm{o}, \beta \mathrm{i}, \beta \mathrm{ii}, \beta \mathrm{ij}$ are intercept, linear, quadratic and interaction constant coefficients respectively; $\mathrm{n}$ is the number of independent factors studied and optimized ( 3 in this case) whereas $\mathrm{Xij}$ is the coded independent variable. Experiments were conducted using combinations of the independent variables at the optimum conditions to validate the model, Regression and graphical analyses were carried out using Design Expert@ version 12. The quality of the model was evaluated using the coefficients of variation $\left(\mathrm{R}^{2}\right)$ and analysis of variance (ANOVA). Response surface plots were drawn by varying two of the independent variables while keeping the third variable constant. 


\section{Results and discussion}

\subsection{Physicochemical properties of mixed oil and biodiesel}

ASTM D751 and EN14214 standards as well as empirical formulas suggest by different scholars were used to investigate various physicochemical properties of biodiesel produced from mixed oil under the optimal conditions to confirm its suitability in the existing engine. Cetane number (CN) and caloric value were estimated by Eqs. (11) and (12) using results of IV and SV. The physicochemical properties determined were specific gravity, density at 20 ${ }^{\circ} \mathrm{C}$, kinematic viscosity at $40{ }^{\circ} \mathrm{C}$, iodine value, flash point, cetane number, heating value, saponification value, acid and free fatty acid values. Table 2 shows the physicochemical properties of mixed oil and biodiesel compared to ASTM D751 and EN 14214 standards.

Cetane number $(\mathrm{CN})$ is a measure of ignition quality of a fuel. The higher the $\mathrm{CN}$ value, the easier the biodiesel ignites when injected into an engine. Biodiesel has a higher $\mathrm{CN}$ value (46-60) because of its higher oxygen content. Cetane number of mixed oil was found to be 57.44 while it was 58.12 for the biodiesel produced from it. The SV ( $\mathrm{mg} \mathrm{KOH} \mathrm{g}^{-1}$ ) of mixed oil was found to be 180.90, a value within acceptable range. Higher SV decreases biodiesel yield by forming soap in presence of an alkaline catalyst. Thus a lower SV is preferred to obtain a higher yield. The IV measures the degree of unsaturation the oil. A higher IV may lead to deposit formation in engine injectors. The IV of the mixed oil was found to be 83.82 $\mathrm{g} \mathrm{I}_{2}$ per $100 \mathrm{~g}$ oil, a result within acceptable range. The IV of biodiesel was found to be 82.22 $\mathrm{g} \mathrm{I}_{2}$ per $100 \mathrm{~g}$ which is within acceptable range of ASMT standards. To determine the oil content of dried microalgae paste, $2.54 \mathrm{~kg}$ biomass was used to extract $800.40 \mathrm{~g}$ of oil using methanol as solvent. A $100 \mathrm{~g}$ of milled castor seed paste was used to extract $46.20 \mathrm{~g}$ of castor oil using methanol as solvent. The use of methanol to extract oil is that both oils contain unsaturated fatty acids which are soluble in methanol [18]. The oil content of microalgal paste and milled castor seeds was estimated using Eq. (2) and found to be $31.51 \%$ and $46.21 \%$ respectively. These results are in a good agreement with the results reported in the literature for castor seeds (46-55\%) and microalgae (20-50\%). The acid and free fatty acid values of the mixed oil $\left(0.21 \mathrm{mg} \mathrm{KOH} \mathrm{g}^{-1}\right.$ and $0.10 \mathrm{mg} \mathrm{KOH} \mathrm{g}^{-1}$ respectively) signify that the oil must be neutralized before converted to biodiesel via transesterification using alkaline 
catalyst. Accordingly the acid value of mixed oil was neutralized with $0.50 \mathrm{~N} \mathrm{NaOH}$ to reduce the AV to less than $0.050 \%$. The density of mixed oil at $20^{\circ} \mathrm{C}$ was found $890 \mathrm{~kg} \mathrm{~m}^{-3}$ while it was $920 \mathrm{~kg} \mathrm{~m}^{-3}$ for the biodiesel produced from it. Viscosity of biodiesel increases with increase in the fatty acid chain. Reducing viscosity is the main objective for the transesterification of oils. This is due to the fact that, viscosity affects the formation of engine deposits and atomization during fuel injection into combustion chamber [33]. The viscosity of biodiesel produced from the mixed oil is within acceptable range of ASTM D6751 standards. Flash point is the minimum temperature at which the vapour above a fuel becomes flammable. It is an important parameter to assess fire risk during transportation, storage and use of biodiesel. Petro-diesels have flash points $50-80{ }^{\circ} \mathrm{C}$ while biodiesel has a flashpoint of over $160{ }^{\circ} \mathrm{C}$. The flash pint of the biodiesel from mixed oil falls within both EN 14214 and ASTM D6751 standards. The results revealed that there is a significant improvement in the physicochemical properties of the biodiesel derived from the mixed oil.

The FFA composition of mixed oil and biodiesel produced from it was analyzed using Gas chromatography. GC analysis of microalgal oil indicates that it is composed of unsaturated fatty acids: palmitolleic (16:1), oleic (18:1), linoleic (18:2), linolenic acid (18:3) and a small amount of saturated fatty acids: palmitic (16:0) and stearic (18:0). On the other hand the castor oil is composed of ricinoleic acid (C18:1OH), linoleic acid (C18:2), oleic acid (C18:1), palmitic acid (C16:0), stearic acid (C18:0) and linolenic acid (C18:3).

\subsection{Optimization of transesterification conditions by RSM}

\subsubsection{Model fitting and analysis of variance}

Response surface methodology comprising of central composite design (CCD) with five level-three factor design was used to optimize conditions for transesterification of mixed oil (Table 4). The results of seventeen experiments designed by CCD were analyzed using Design-Expert@ software version 12. A quadratic polynomial equation consisting of a center point, three linear coefficients $(A, B, C)$, three quadratic coefficients $\left(A^{2}, B^{2}, C^{2}\right)$ and three interaction coefficients $(\mathrm{AB}, \mathrm{AC}, \mathrm{BC})$ was obtained from the design experiment for predicting the yield of biodiesel in terms of code factors using Eq. (18):

Biodiesel yield $=91.28+11.69 \mathrm{~A}+4.76 \mathrm{~B}-0.83 \mathrm{C}-5.15 \mathrm{AB}+1.84 \mathrm{AC}-1.63 \mathrm{BC}-8.20 \mathrm{~A}^{2}-$

$3.54 B^{2}-0.069 C^{2}$ 
However, only terms with $\mathrm{P}$-value $<0.05$ were included in the final model equation for characterizing the response. The model was analyzed statistically to evaluate the analysis of variance (ANOVA) and if adequate to fit. The P-value of the model is $<0.0001$ indicating high significance in predicting the response and suitability of the model. The $\mathrm{F}$ value of model $(\mathrm{F}=54.96)$ with very low P-value $(<0.0001)$ indicates the high significance of the fitted model. A small coefficient of variation $(\mathrm{CV}=5.39 \%)$ indicates the reliability of fitted model. The quality of the model fit was evaluated using the coefficient of variation $\left(\mathrm{R}^{2}=\right.$ 0.9860 , implies $98.6 \%$ of the experimental data are compatibility with the data predicted by the model).

The significance of each coefficient of response surface model was evaluated using Pvalues. Accordingly only A (catalyst concentration linear term, $\mathrm{P}<0.0001$ ), B (molar ratio of ethanol to oil linear term, $\mathrm{P}=0.0003$ ), $\mathrm{A}^{2}$ (catalyst concentration quadratic term, $\mathrm{P}<0.0001$ ), $\mathrm{B}^{2}$ (ethanol to oil molar ratio quadratic term, $\mathrm{P}=0.0028$ ) and $\mathrm{AB}$ (interaction between catalyst concentration and ethanol to oil molar ratio, $\mathrm{P}=0.0011$ ) coefficients were significant. All coefficients containing temperature terms (linear, interactions, quadratic) were not significant (Table 4). The adjusted coefficient of variation was used to rewrite model equation using all the significant terms. A very high value of the adjusted coefficient of variation $\left(\mathrm{R}^{2}\right.$ adjusted $\left.=0.968\right)$ indicates the model is very significant. A reasonable precision of the fitted model was deduced from a higher value of predicted coefficient of variation $\left(\mathrm{R}^{2}\right.$ predicted $\left.=0.9214\right)$. A reasonably high value of coefficient of variation $\left(\mathrm{R}^{2}=\right.$ 0.9860) indicates that the model is in agreement with the observed values over the selected range of operating parameters (Fig. 7).

\subsubsection{Effects of the process variables on the yield of biodiesel}

Design Expert ${ }^{\circledR} 12$ software was used to draw response surface plots using the regression model equation. Since individual plot does not show the significant interaction between parameters, 3D surface and contour plots were drawn to show the interaction effect of process variables on biodiesel yield. Each contour plot represents effect of two independent variables on the biodiesel yield, keeping the third variable at a fixed level. Based on $95 \%$ confidence limit, only those terms with $\mathrm{P}$-value $<0.05$ were considered in the final quadratic model equation to investigate the effect of independent variables on biodiesel yield. The reduced significant model equation is: 
$\mathrm{Z}=91.28+11.69 \mathrm{~A}+4.76 \mathrm{~B}-5.15 \mathrm{AB}-8.20 \mathrm{~A}^{2}-3.54 \mathrm{~B}^{2}$

Accordingly, the linear and quadratic terms of ethanol to oil molar ratio and catalyst concentration $\left(\mathrm{A}, \mathrm{A}^{2}\right.$ and $\mathrm{B}, \mathrm{B}^{2}$ ) were statistically significant. On the other hand, all the interaction terms were not statistically significant except for ethanol to mixed oil molar ratio and catalyst concentration $(\mathrm{AB})$.

The effect ethanol to mixed oil molar ratio and catalyst concentration on yield of biodiesel at a constant reaction temperature of $50{ }^{\circ} \mathrm{C}$ is shown in Fig. 8. The relationship between percent yield of biodiesel and catalyst concentration is curvilinear with a positive linear coefficient and a negative quadratic coefficient indicating that yield of biodiesel is inhibited beyond the optimum catalyst concentration might be because revers reaction is favored at higher catalyst concentration. At low ethanol to oil molar ratio, the yield of biodiesel was improved with increase in catalyst concentration. Increasing both molar ratio and catalyst concentration at the same time also improved the yield of biodiesel, indicating that there is significant interaction between mixed oil molar ratio and catalyst concentration.

The effect of reaction temperature and catalyst concentration on the yield of biodiesel at a constant ethanol to oil molar ratio of 7.5:1 is shown in Fig. 9. The effect of reaction temperature $\left({ }^{\circ} \mathrm{C}\right)$ and its interactions with catalyst concentration was not significant at Pvalue $=0.05$, indicating that temperature does not significantly affect the yield of biodiesel for this study. The yield of biodiesel was improved with increases in catalyst concentration towards $1.23 \%$ at room temperature and after that there was substantial decrease in the yield with further increase in catalyst concentration. This might be due to the fact that excess amount of catalyst concentration might lead to soap formation. The formation of soap occurs due to saponification reaction at higher catalytic concentration beyond $1.25 \%$.

The effect of molar ratio, reaction temperature and their combined interaction at constant catalyst concentration of $1 \%$ is shown in Fig. 10. The effect of reaction temperature and its interactions with molar ratio $(\mathrm{BC})$ was not significant at $\mathrm{P}$-value $=0.05$, indicating that temperature does not significantly affect the yield of biodiesel might be due to the fact that the mixed oil is soluble in ethanol at room temperature. At low catalyst concentration increasing temperature had very little effect on the yield of biodiesel. Increasing molar ratio beyond the optimal will increase cost for alcohol recovery rather than increasing yield of biodiesel [26]. 


\subsubsection{Optimization and validation of the yield of biodiesel}

The Design-Expert ${ }^{\circledR}$ software was used to solve the regression equation to obtain optimal values for the three independent variables. To solve the regression equation the goal of the three independent variables was set to "in range" while the goal of the response (percent of biodiesel yield) was set to "maximize". Both the lower and upper weights were set to one while importance was set at 3 (Table 5). The predicted optimal values from the model were catalyst concentration of $1.23 \%$, ethanol to oil molar ratio of 5.94:1 and reaction temperature of $51.31{ }^{\circ} \mathrm{C}$. The model predicts that the maximum biodiesel yield under these optimum conditions is $93.88 \%$. To validate result predicted by model, experiment was conducted under the specified optimum conditions. The yield of biodiesel from the experiment is 93.36\% which is very close to the value predicted by the model (Table 6).

\section{Conclusions}

This study was conducted to optimize biodiesel production parameters derived from mixed castor and microalgae oils. A 1:1 ratio of mixed oil was converted to biodiesel by transesterification process using $\mathrm{KOH}$. RSM based on CCD was used to maximize biodiesel yield from the oil. The optimum operating parameters for transesterification of mixed oil at $500 \mathrm{rpm}$ and reaction time of one hour were ethanol-to-oil molar ratio (5.94:1), catalyst concentration (1.23\%) and reaction temperature $\left(51.31{ }^{\circ} \mathrm{C}\right)$. Under these operating parameters the highest yield of biodiesel was 93.36\%. ASTM D6571 and EN14214 standards were used to analysis fuel properties of biodiesel produced under the optimal conditions to confirm its suitability to the existing diesel engine. Study of physic-chemical properties of the biodiesel produced from mixed oil reveals that the properties are within standards. Optimization of process parameters for biodiesel production derived from mixed feedstocks is very important to improve the fuel properties of biodiesel. Thus, it can be concluded that the optimized biodiesel from mixed oil can be a potential substitute of diesel fuel but engine performance and exhaust emissions should be studied.

\section{Declarations}

\section{Availability of data and materials}

The data used to support the findings of this study are available from the corresponding author upon request. 


\section{Competing interests}

The authors declare no competing interests.

\section{Funding}

The authors declare the study received no external funding

Authors' contributions

All the authors contributed equally and they read and approved the final manuscript.

\section{Acknowledgements}

The authors would like to acknowledge Jimma University, Jimma Institute of Technology for providing analytical instruments to conduct this study.

\section{References}

1. Hanna M, Fangrui M (1999) Biodiesel production: a review 1. Bioresour Technol 70:1-15

2. Nwabuokei JTNPI (2019) Optimization of Biodiesel Production from Castor Seed Oil Using NaOH Catalyst. Int J Sci Res 8:2046-2050

3. Banković-Ilić IB, Stamenković OS, Veljković VB (2012) Biodiesel production from non-edible plant oils. Renew Sustain Energy Rev 16:3621-3647

4. Yusuf A., Mamza PA., Ahmed, A S, Agunwa U (2015) Extraction And Characterization Of Castor Seed Oil. Internet J Nutr Wellness. https://doi.org/10.5580/147f

5. Salihu BZ, Gana AK, Apuyor BO (2014) Castor Oil Plant ( Ricinus communis L .): Botany , Ecology and Uses. Int J Sci Res 3:1333-1341

6. Leung DYC, Guo Y (2006) Transesterification of neat and used frying oil: Optimization for biodiesel production. Fuel Process Technol 87:883-890

7. De Lima Da Silva N, Batistella ĆB, Filho RM, Maciel MRW (2009) Biodiesel production from castor oil: Optimization of alkaline ethanolysis. Energy and Fuels 23:5636-5642

8. Pradhan S, Madankar CS, Mohanty P, Naik SN (2012) Optimization of reactive extraction of castor seed to produce biodiesel using response surface methodology. Fuel 97:848-855

9. Avhad MR, Marchetti JM (2015) A review on recent advancement in catalytic 
materials for biodiesel production. Renew Sustain Energy Rev 50:696-718

10. Hassani M, Najafpour GD, Mohammadi M (2016) Transesterification of waste cooking oil to biodiesel using $\gamma$-alumina coated on zeolite pellets. J Mater Environ Sci 7:1193-1203

11. Moser BR (2009) Biodiesel production, properties, and feedstocks. Vitr CellDevBiol 45:229-266

12. Atabani AE, Silitonga AS, Badruddin IA, Mahlia TMI, Masjuki HH, Mekhilef S (2012) A comprehensive review on biodiesel as an alternative energy resource and its characteristics. Renew Sustain Energy Rev 16:2070-2093

13. Bhuiya MMK, Rasul MG, Khan MMK, Ashwath N, Azad AK, Hazrat MA (2016) Prospects of 2nd generation biodiesel as a sustainable fuel - Part 2: Properties, performance and emission characteristics. Renew Sustain Energy Rev 55:1129-1146

14. Johnson WZ and MB (2009) Microalgae as a Feedstock for Biofuel Production. Virginia Coop Ext 11:442-886

15. Deng X, Li Y, Fei X (2009) Microalgae: A promising feedstock for biodiesel. African J Microbiol Res 3:1008-1014

16. Chisti Y (2007) Biodiesel from microalgae. Biotechnol Adv 25:294-306

17. Park YW, Chang PS, Lee JH (2010) Application of triacylglycerol and fatty acid analyses to discriminate blended sesame oil with soybean oil. Food Chem 123:377383

18. Haldar C (2018) Microalgae as a Potential Source of Biofuels and its Current Advances. Examines Mar Biol Oceanogr 2:168-172

19. Moser BR (2008) Influence of blending canola, palm, soybean, and sunflower oil methyl esters on fuel properties of biodiesel. Energy and Fuels 22:4301-4306

20. Qiu F, Li Y, Yang D, Li X, Sun P (2011) Biodiesel production from mixed soybean oil and rapeseed oil. Appl Energy 88:2050-2055

21. Jena PC, Raheman H, Prasanna Kumar G V., Machavaram R (2010) Biodiesel production from mixture of mahua and simarouba oils with high free fatty acids. Biomass and Bioenergy 34:1108-1116

22. Sarin R, Sharma M, Sinharay S, Malhotra RK (2007) Jatropha-Palm biodiesel blends: An optimum mix for Asia. Fuel 86:1365-1371 
23. Dharma S, Masjuki HH, Ong HC, Sebayang AH, Silitonga AS, Kusumo F, Mahlia TMI (2016) Optimization of biodiesel production process for mixed Jatropha curcasCeiba pentandra biodiesel using response surface methodology. Energy Convers Manag 115:178-190

24. Srivastava A, Prasad R (2000) Triglycerides-based diesel fuels. Renew Sustain energy Rev 4:111-133

25. Demirbas A (2005) Biodiesel production from vegetable oils via catalytic and noncatalytic supercritical methanol transesterification methods. Prog Energy Combust Sci $31: 466-487$

26. Leung DYC, Wu X, Leung MKH (2010) A review on biodiesel production using catalyzed transesterification. Appl Energy 87:1083-1095

27. Freedman B, Pyde E., MOUNTs T. (1984) Cs 1. https://doi.org/10.1145/3017680.3017802

28. Indhumathi P, Syed Shabudeen PS, Shoba US (2014) A method for production and characterization of biodiesel from green micro algae. Int J Bio-Science BioTechnology 6:111-122

29. Hurtado B, Posadillo A, Luna D, Bautista FM, Hidalgo JM, Luna C, Calero J, Romero AA, Estevez R (2019) Synthesis, performance and emission quality assessment of ecodiesel from castor oil in diesel/biofuel/alcohol triple blends in a diesel engine. Catalysts. https://doi.org/10.3390/cata19010040

30. Demirbas A, Ak N, Aslan A, Sen N (2018) Calculation of higher heating values of hydrocarbon compounds and fatty acids. Pet Sci Technol 36:712-717

31. Nivea DLDS, Regina M, Maciel W, Batistella C, Filho RM (2006) Optimization of Biodiesel Production N IVEA DE L IMA DA S ILVA ,* M ARIA R EGINA W OLF M ACIEL ,. J Food Hyg Soc Japan 1:1-3

32. Nakpong P, Wootthikanokkhan S (2010) Roselle (Hibiscus sabdariffa L.) oil as an alternative feedstock for biodiesel production in Thailand. Fuel 89:1806-1811

33. Bouaziz M, Mahafoudhi M, Jebeur H, Neji SB (2017) Biodiesel Production from Raw Tunisian Castor Oil and Its Application as Alternative Fuel. Arch Pet Environ Biotechnol. https://doi.org/10.29011/2574-7614.100118 


\section{Tables}

Table 1: Actual and coded values of independent variables used in the CCD

\begin{tabular}{|c|c|c|c|c|c|c|c|}
\hline \multirow[t]{3}{*}{ Factor } & \multirow[t]{3}{*}{ Symbol } & \multirow[t]{3}{*}{ Unit } & \multicolumn{5}{|c|}{ Coded levels of independent factors } \\
\hline & & & -1.68 & -1 & 0 & +1 & +1.68 \\
\hline & & & \multicolumn{5}{|c|}{ Actual levels of independent factors } \\
\hline Catalyst concentration & A & $\%$ & 0.50 & 0.70 & 1 & 1.3 & 1.5 \\
\hline Alcohol to oil ratio & B & $\mathrm{v} / \mathrm{v}$ & 3 & 5 & 7.5 & 10 & 12 \\
\hline Reaction temperature & $\mathrm{C}$ & ${ }^{\circ} \mathrm{C}$ & 25 & 35 & 50 & 65 & 75 \\
\hline
\end{tabular}

Table 2: Physicochemical properties of mixed oil and biodiesel made from it

\begin{tabular}{llcccc}
\hline Physicochemical property & Unit & \multicolumn{2}{c}{ Values } & \multicolumn{2}{c}{ Biodiesel standards } \\
\cline { 3 - 5 } & & Mixed oil & Biodiesel & ASTM D751 & EN 14214 \\
\hline Specific gravity & - & 0.89 & 0.920 & $0.86-0.90$ & $0.86-0.90$ \\
Density at $20^{\circ} \mathrm{C}$ & $\mathrm{kg} \mathrm{m}^{-3}$ & 890 & 920 & $860-900$ & $860-900$ \\
Kinematic viscosity @ $40{ }^{\circ} \mathrm{C}$ & $\mathrm{mm}^{2} \mathrm{~s}^{-1}$ & 44.60 & 5.80 & $1.9-6.0$ & $3.5-5.0$ \\
Flash point & ${ }^{0} \mathrm{C}$ & 160 & 133.33 & $\geq 120$ & $\geq 130$ \\
Cetane number & - & 57.44 & 58.12 & $\geq 47$ & $\geq 51$ \\
Acid value & $\mathrm{mg} \mathrm{KOH} \mathrm{g}^{-1}$ & 0.21 & 0.10 & $\leq 0.05$ & $\leq 0.05$ \\
Free fatty acid value & $\%$ & 0.11 & 0.05 & - & - \\
Saponification value & $\mathrm{mg} \mathrm{KOH} \mathrm{g}^{-1}$ & 180.9 & 1.80 & - & - \\
Iodine Value & $\mathrm{g} \mathrm{I}_{2} / 100 \mathrm{~g}^{2}$ & 83.82 & 82.22 & $\leq 120$ & $\leq 140$ \\
Moisture content & $\%$ & 0.06 & 0.027 & $\leq 0.03$ & Max 0.05 \\
Ash content & $\%$ & 0.045 & 0.028 & $\leq 0.03$ & $\leq 0.02$ \\
Caloric value & $\mathrm{MJ} \mathrm{Kg}^{-1}$ & 43.27 & 48.0 & $\geq 42$ & $\geq 35$ \\
\hline
\end{tabular}

Table 3: Experimental design using CCD and results of mixed oil transesterification

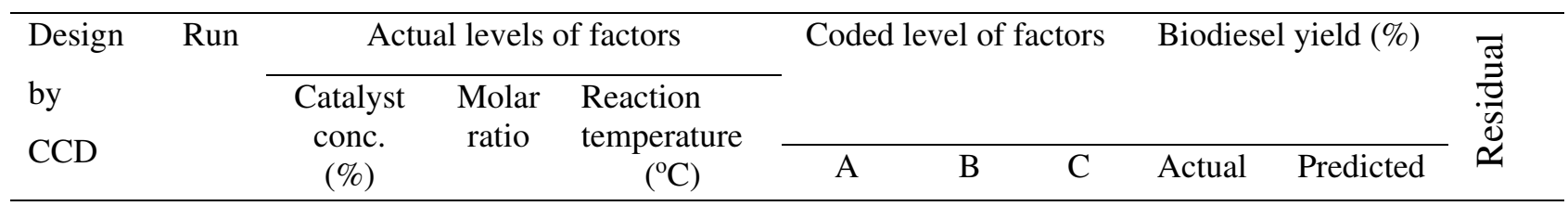




\begin{tabular}{|c|c|c|c|c|c|c|c|c|c|c|}
\hline \multirow{8}{*}{ 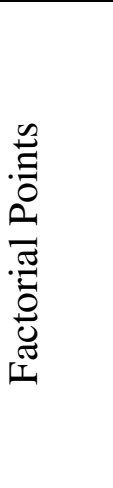 } & 1 & 1.3 & 10 & 35 & 1 & 1 & -1 & 90.87 & 91.67 & -0.80 \\
\hline & 2 & 0.7 & 10 & 35 & -1 & 1 & -1 & 82.22 & 81.50 & 0.72 \\
\hline & 3 & 1.3 & 5 & 65 & 1 & -1 & 1 & 91.94 & 94.53 & -2.59 \\
\hline & 4 & 1.3 & 10 & 65 & 1 & 1 & 1 & 89.44 & 90.66 & -1.22 \\
\hline & 5 & 0.7 & 5 & 35 & -1 & -1 & -1 & 59.19 & 59.83 & -0.64 \\
\hline & 6 & 1.3 & 5 & 35 & 1 & -1 & -1 & 88.49 & 89.43 & -0.94 \\
\hline & 7 & 0.7 & 10 & 65 & -1 & 1 & 1 & 72.13 & 73.06 & -0.93 \\
\hline & 8 & 0.7 & 5 & 65 & -1 & -1 & 1 & 56.44 & 57.51 & -1.07 \\
\hline \multirow{6}{*}{ 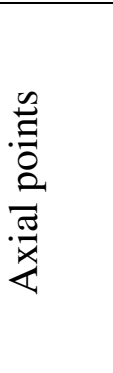 } & 9 & 1.5 & 7.5 & 50 & 2 & 0 & 0 & 90.19 & 87.76 & 2.43 \\
\hline & 10 & 1 & 12 & 50 & 0 & 2 & 0 & 89.59 & 89.28 & 0.31 \\
\hline & 11 & 0.5 & 7.5 & 50 & -2 & 0 & 0 & 48.68 & 48.43 & 0.25 \\
\hline & 12 & 1 & 3 & 50 & 0 & -2 & 0 & 75.25 & 73.26 & 1.99 \\
\hline & 13 & 1 & 1.5 & 75 & 0 & 0 & 2 & 92.23 & 89.68 & 2.55 \\
\hline & 14 & 1 & 7.5 & 25 & 0 & 0 & -2 & 92.57 & 92.48 & 0.09 \\
\hline \multirow{3}{*}{ 离 } & 15 & 1 & 7.5 & 50 & 0 & 0 & 0 & 93.34 & 91.28 & 2.06 \\
\hline & 16 & 1 & 7.5 & 50 & 0 & 0 & 0 & 92.43 & 91.28 & 1.15 \\
\hline & 17 & 1 & 7.5 & 50 & 0 & 0 & 0 & 87.89 & 91.28 & -3.39 \\
\hline
\end{tabular}

Table 4: Analysis of variance for fitting the response surface quadratic model

\begin{tabular}{lcccccc}
\hline $\begin{array}{l}\text { Variation } \\
\text { source }\end{array}$ & Sum of squares & DF & Mean square & F-value & P-value & \\
\hline Model & 3268.62 & 9 & 363.18 & 54.96 & $<0.0001$ & Significant \\
\hline A-Catalyst & 1887.19 & 1 & 1887.19 & 285.61 & $<0.0001$ & \\
B-Molar ratio & 286.53 & 1 & 286.53 & 43.36 & 0.0003 & \\
C-Temperature & 9.50 & 1 & 9.50 & 1.44 & 0.2695 & \\
\hline AB & 188.57 & 1 & 188.57 & 28.54 & 0.0011 & \\
AC & 27.60 & 1 & 27.60 & 4.18 & 0.0803 & \\
BC & 18.67 & 1 & 18.67 & 2.82 & 0.1367 & \\
\hline A $^{2}$ & 750.30 & 1 & 750.30 & 113.55 & $<0.0001$ & \\
$B^{2}$ & 134.19 & 1 & 134.19 & 20.31 & 0.0028 & \\
$C^{2}$ & 0.0522 & 1 & 0.0522 & 0.0079 & 0.9317 & \\
\hline Residual & 46.25 & 7 & 6.61 & - & - & Not significant \\
Lack of fit & 29.21 & 5 & 5.84 & 0.6853 & 0.6832 &
\end{tabular}




$\begin{array}{lccccc}\text { Pure error } & 17.05 & 2 & 8.52 & - & - \\ \text { Total } & 3314.88 & 16 & - & - & -\end{array}$

$\mathrm{CV}=5.39 ; \quad \mathrm{R}^{2}=0.9860 ; \mathrm{R}^{2}($ adjusted $)=0.9681 ; \mathrm{R}^{2}($ predicted $)=0.9214$

Table 5: Optimization of transesterification process variables under optimum conditions

\begin{tabular}{|c|c|c|c|c|c|c|}
\hline Constraint name & Goal & $\begin{array}{c}\text { Lower } \\
\text { limit }\end{array}$ & $\begin{array}{l}\text { Upper } \\
\text { limit }\end{array}$ & $\begin{array}{l}\text { Lower } \\
\text { weight }\end{array}$ & $\begin{array}{l}\text { Upper } \\
\text { weight }\end{array}$ & Importance \\
\hline Catalyst conc. & In range & 0.70 & 1.30 & 1 & 1 & 3 \\
\hline Molar ratio & In range & 4.8 & 10.20 & 1 & 1 & 3 \\
\hline Temperature & In range & 35 & 65 & 1 & 1 & 3 \\
\hline Biodiesel yield & Maximum & 48.68 & 93.34 & 1 & 1 & 3 \\
\hline \multicolumn{7}{|c|}{ Solution } \\
\hline Solution number & $\begin{array}{l}\text { Catalyst } \\
\text { Conc. }\end{array}$ & $\begin{array}{l}\text { Molar } \\
\text { ratio }\end{array}$ & $\begin{array}{c}\text { Reaction } \\
\text { temperature }\end{array}$ & $\begin{array}{c}\text { Biodiesel } \\
\text { yield }\end{array}$ & Desirability & Status \\
\hline 1 & 1.23 & 5.94 & 51.31 & 93.88 & 1.00 & Selected \\
\hline
\end{tabular}

Table 6: Model validation by experimental results under optimum conditions

\begin{tabular}{lcccc}
\hline & Optimum condition & \multicolumn{2}{c}{ Biodiesel yield (\%) } \\
\hline Catalyst & Molar ratio & Temperature & Experimental & Model \\
Conc. $(\%)$ & $(\mathrm{v} / \mathrm{v})$ & $\left({ }^{\circ} \mathrm{C}\right)$ & result & predicted \\
\hline 1.23 & 5.94 & 51.31 & 93.36 & 93.88 \\
\hline
\end{tabular}




\section{Figures}

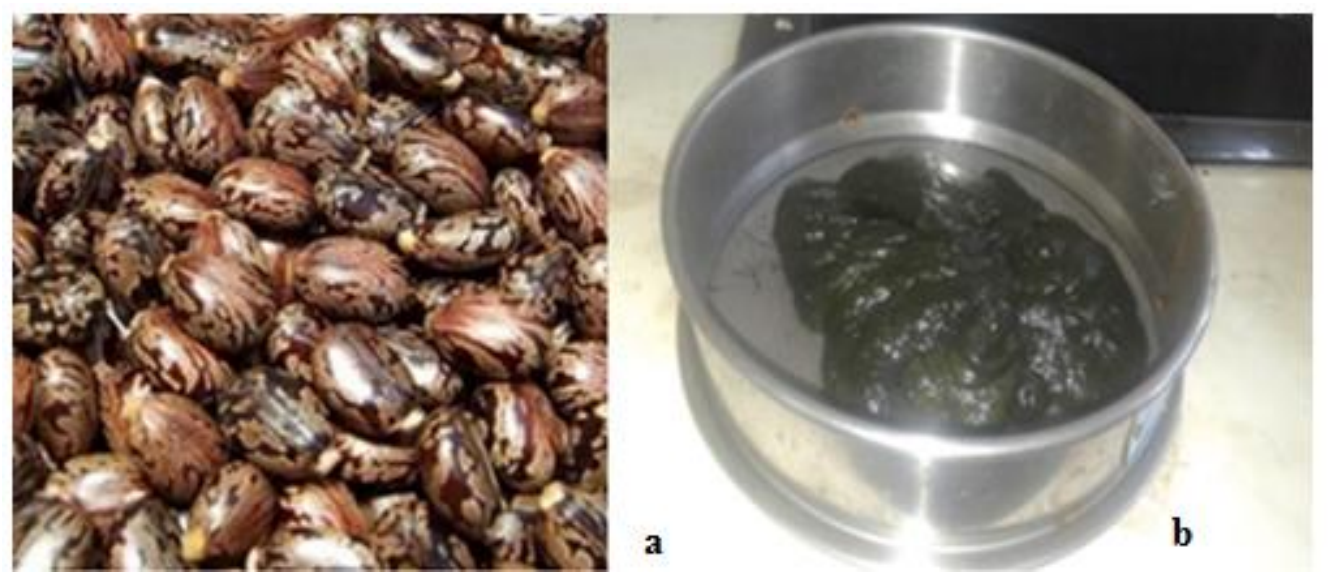

Fig. 1: Samples of raw castor seeds (a) and microalgae biomass (b) used for oil extraction

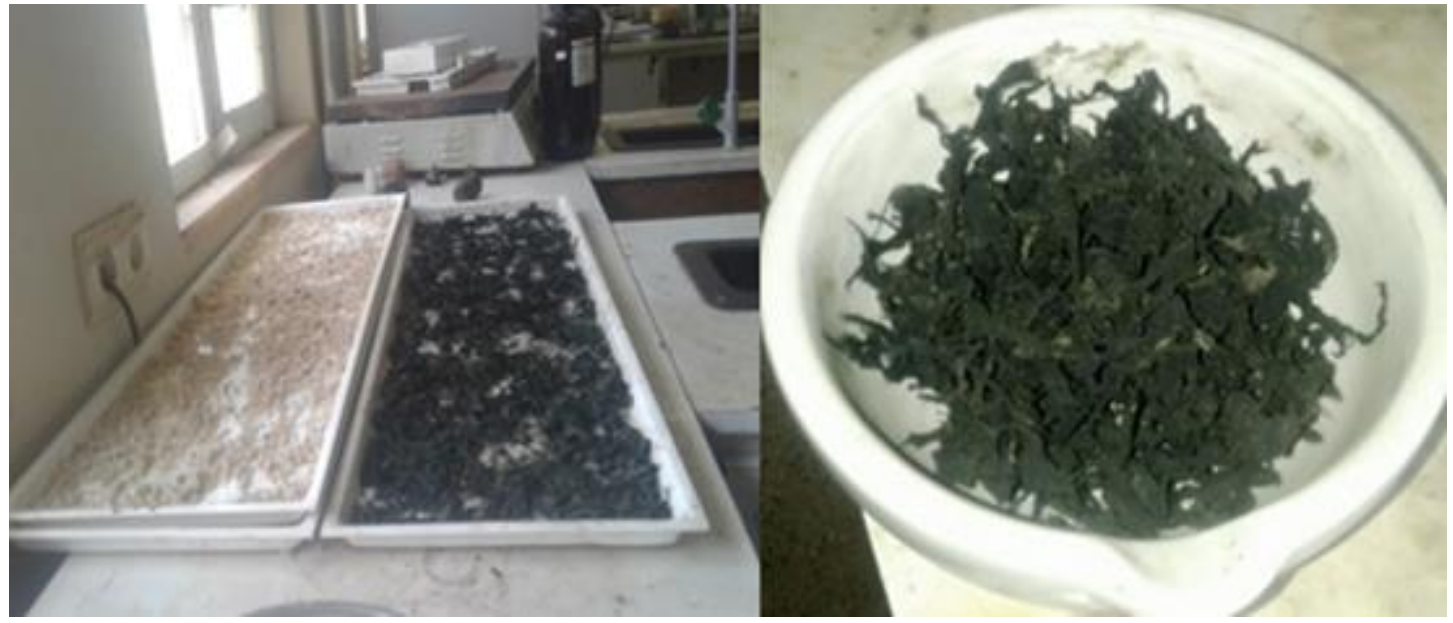

Fig. 2: Preparation of microalgal past

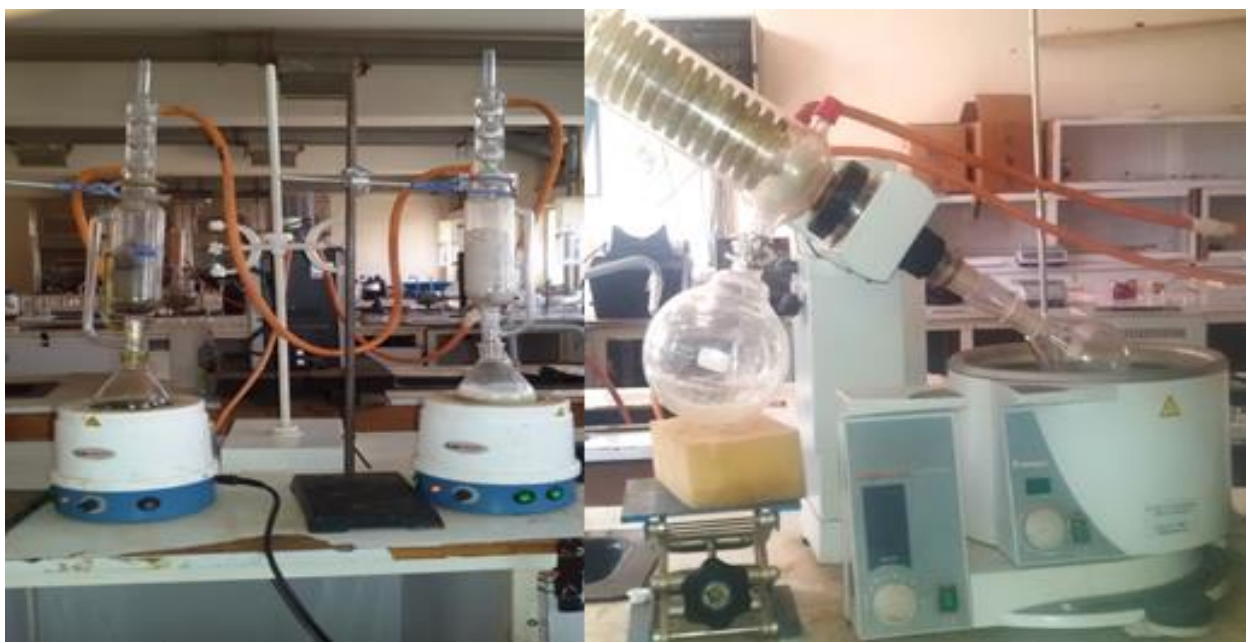

Fig. 3: Soxlet apparatus and Rotary evaporator setup for oil extraction and purification 


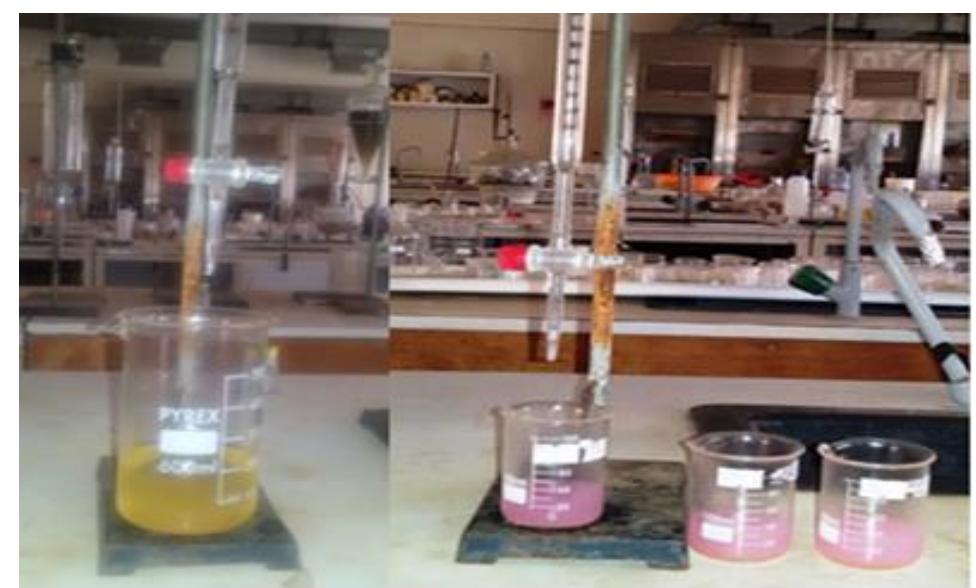

Fig. 4: Experimental determinations of acid value of mixed oil and biodiesel samples

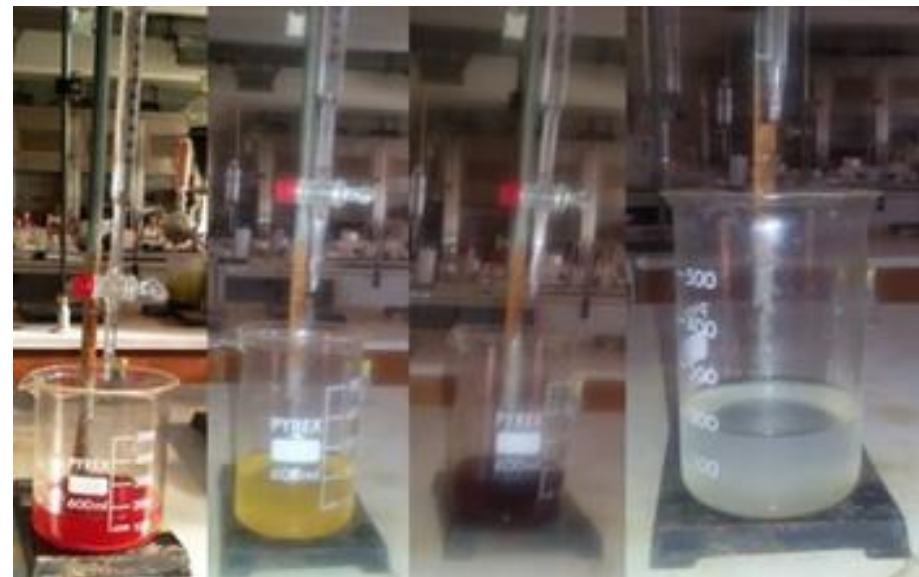

Fig. 5: Determination of iodine value by titration method

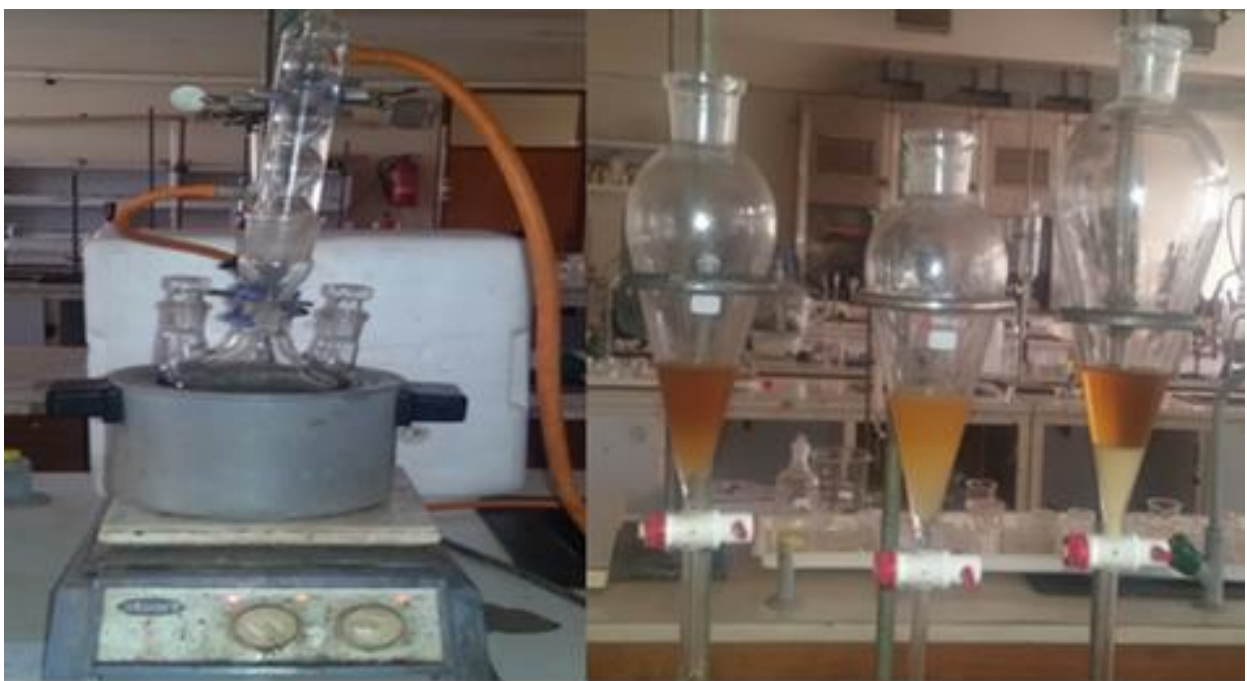

Fig. 6: Mixed oil tranisterification and separation of resulting biodiesel 


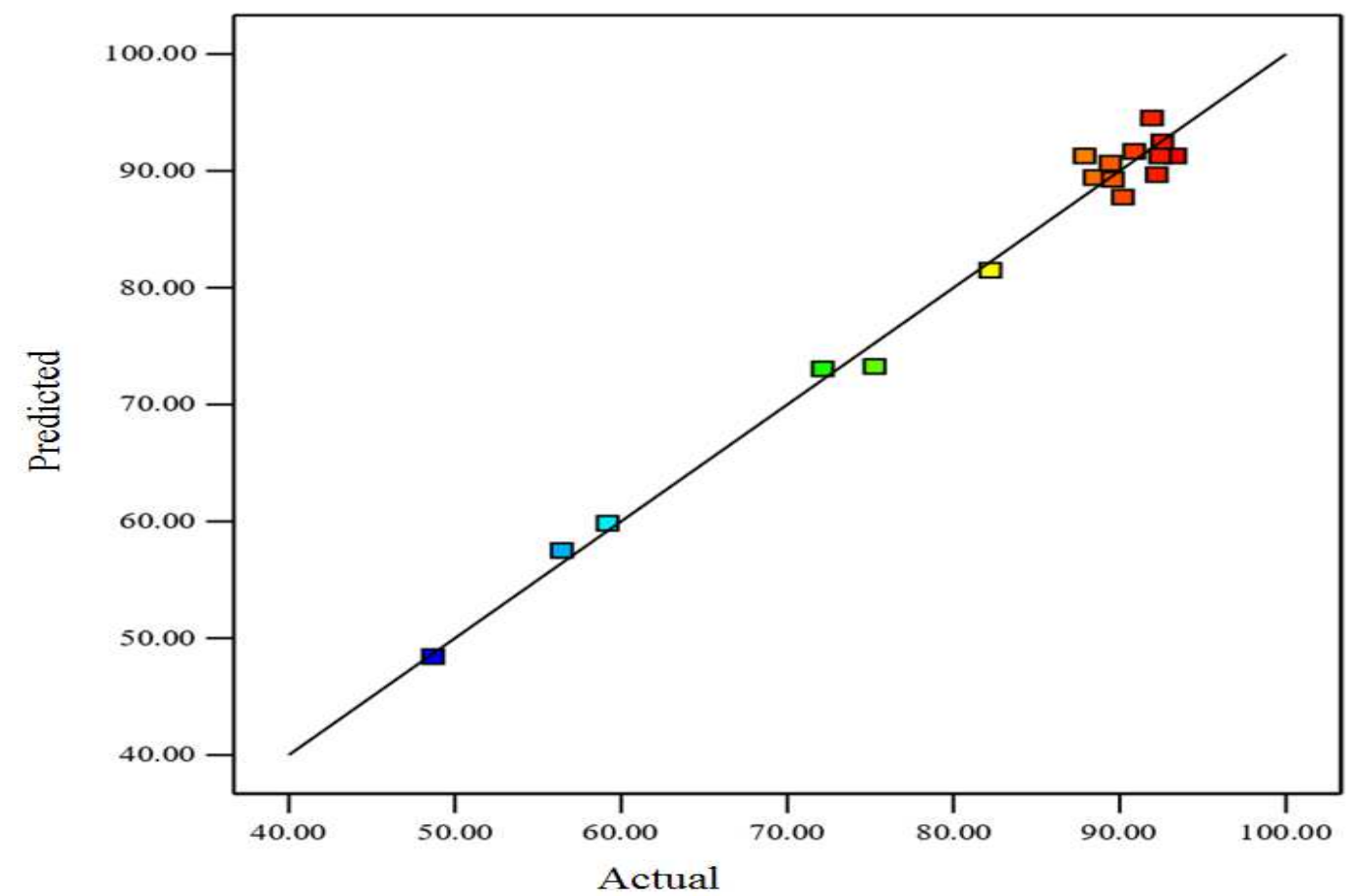

Fig. 7: Comparison between actual and predicted value of biodiesel yield

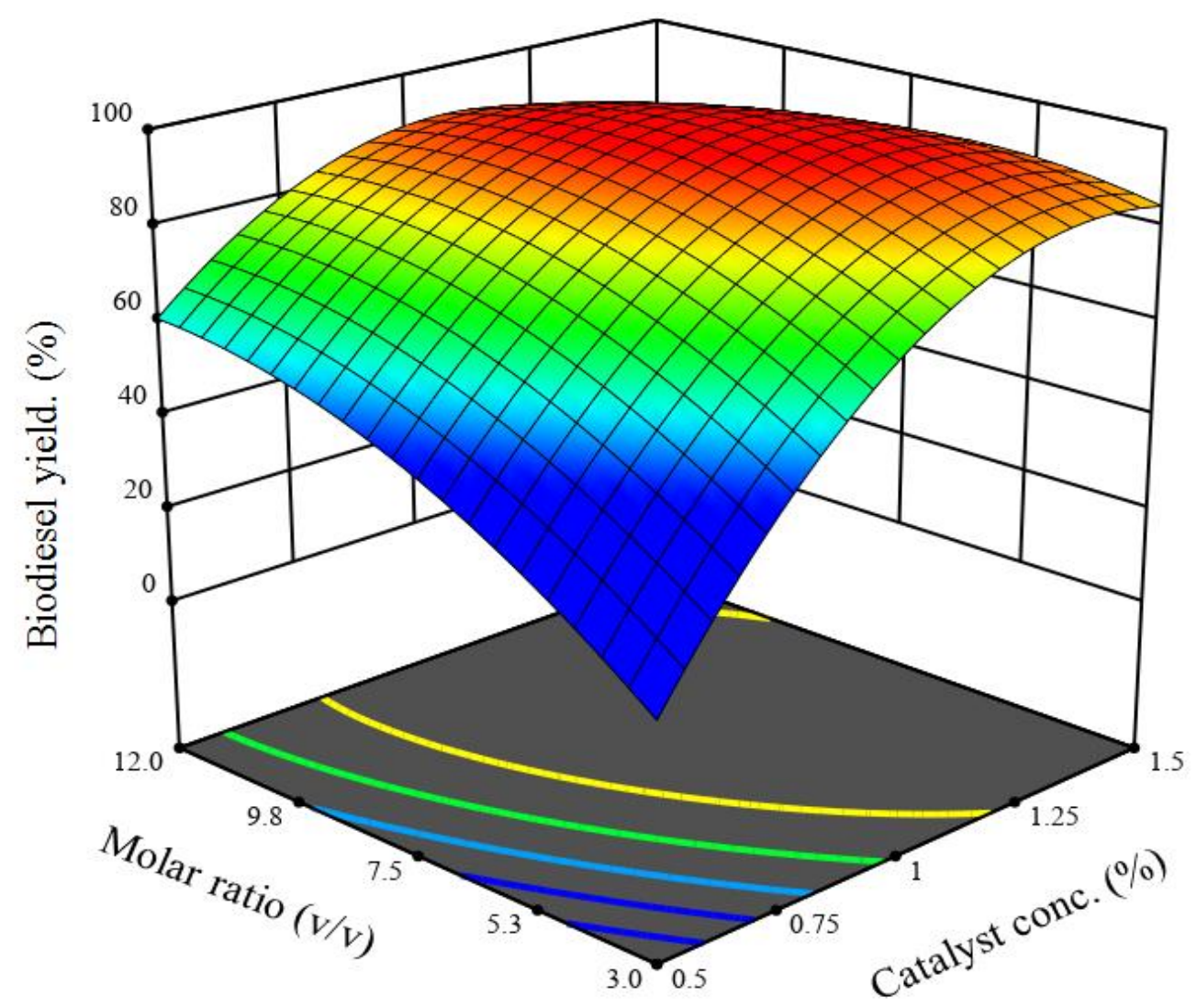

Fig. 8: Effect of ethanol to oil molar ratio and catalyst concentration on yield of biodiesel at constant reaction temperature of $50^{\circ} \mathrm{C}$ 


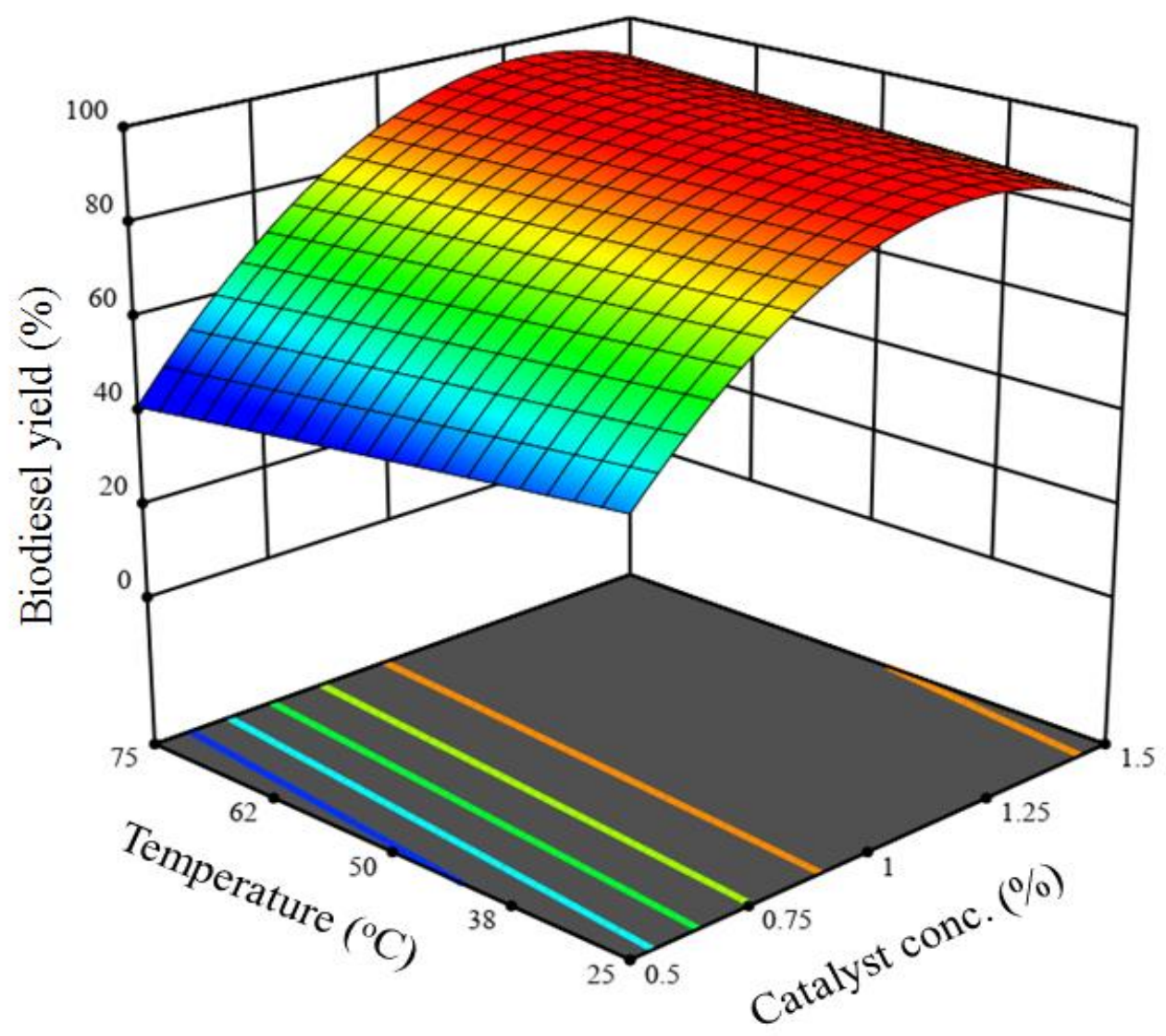

Fig. 9: Effect of reaction temperature and catalyst concentration on yield of biodiesel at constant ethanol to oil molar ratio of 7.5:1 


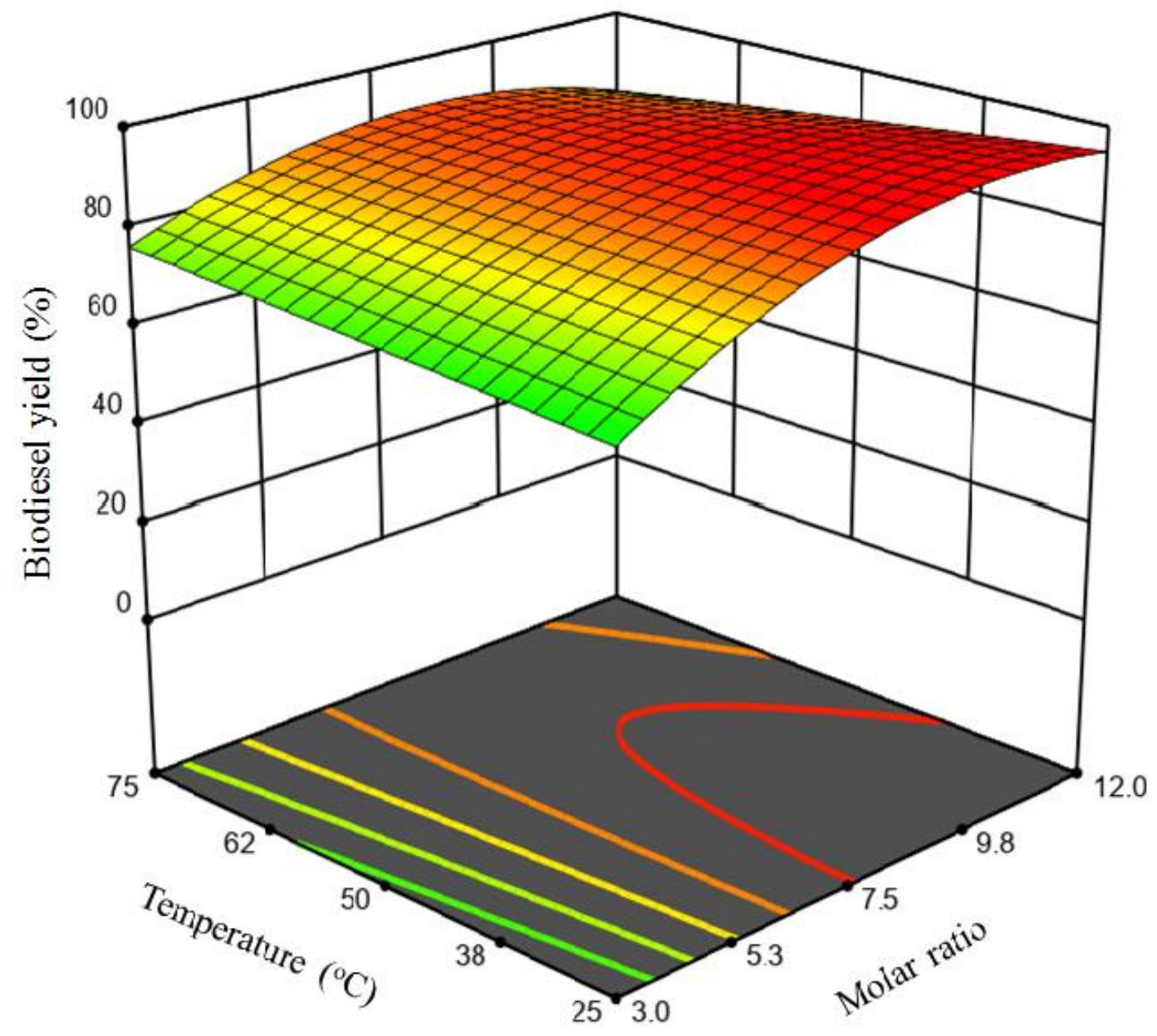

Fig. 10: Effect of reaction temperature, ethanol to oil molar ratio and their combined interaction on the yield of biodiesel at constant catalyst concentration of $1 \%$. 


\section{Figures}
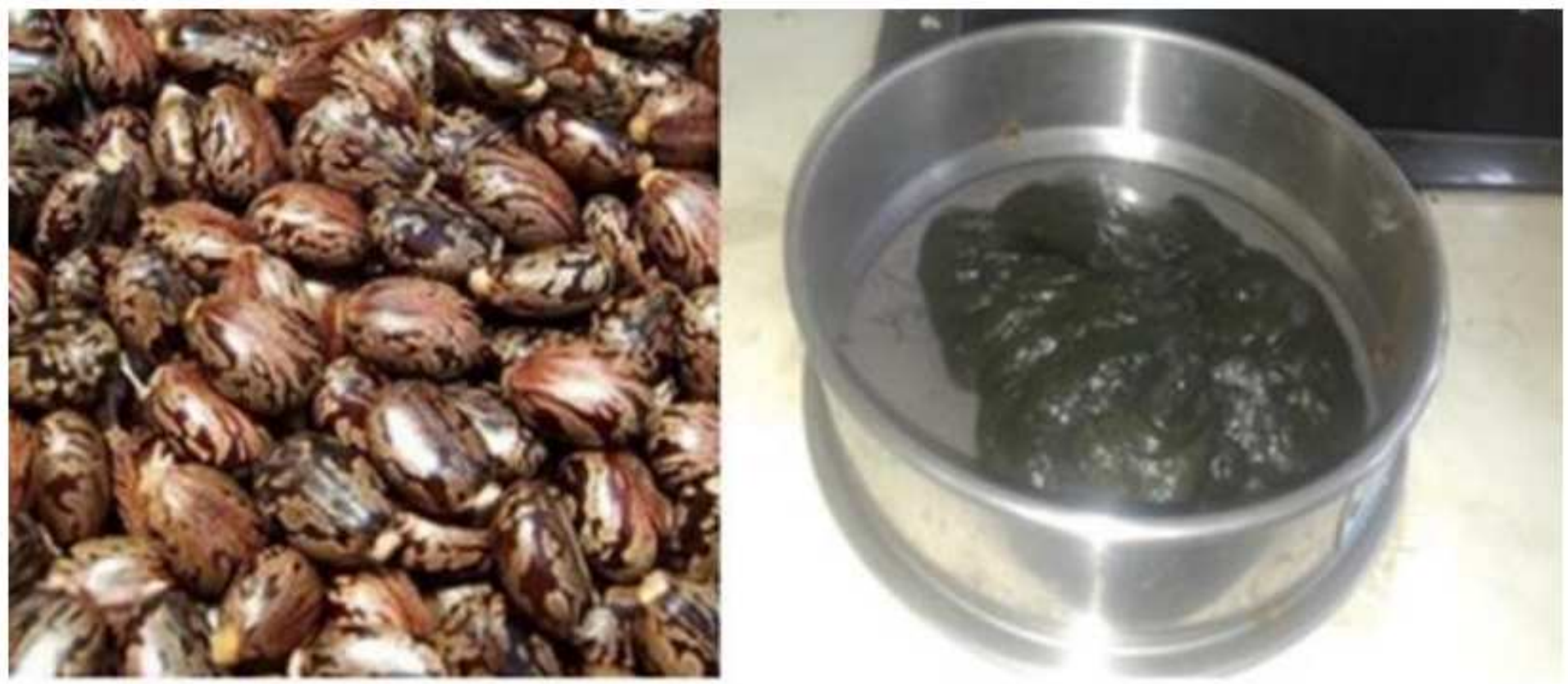

Figure 1

Samples of raw castor seeds and microalgae biomass used for oil extraction

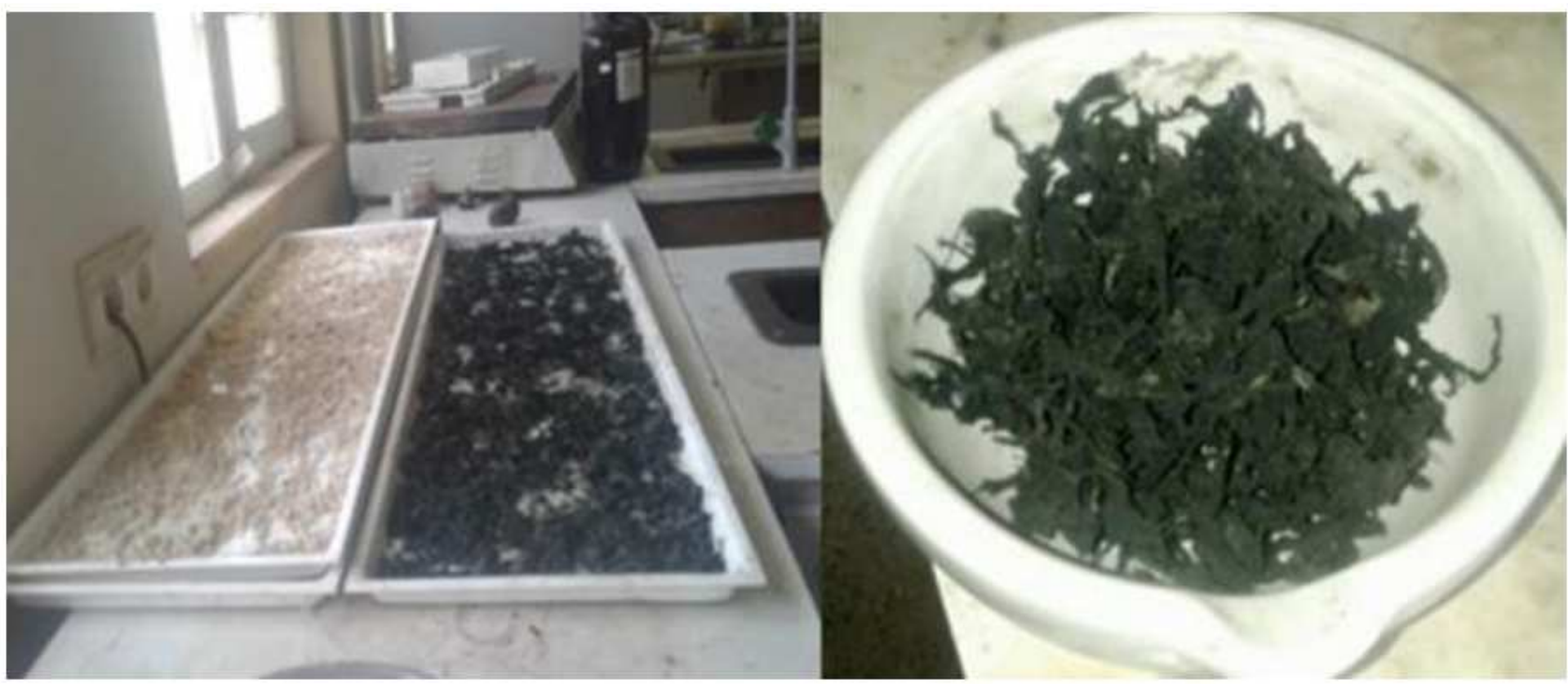

Figure 2

Preparation of microalgal past 


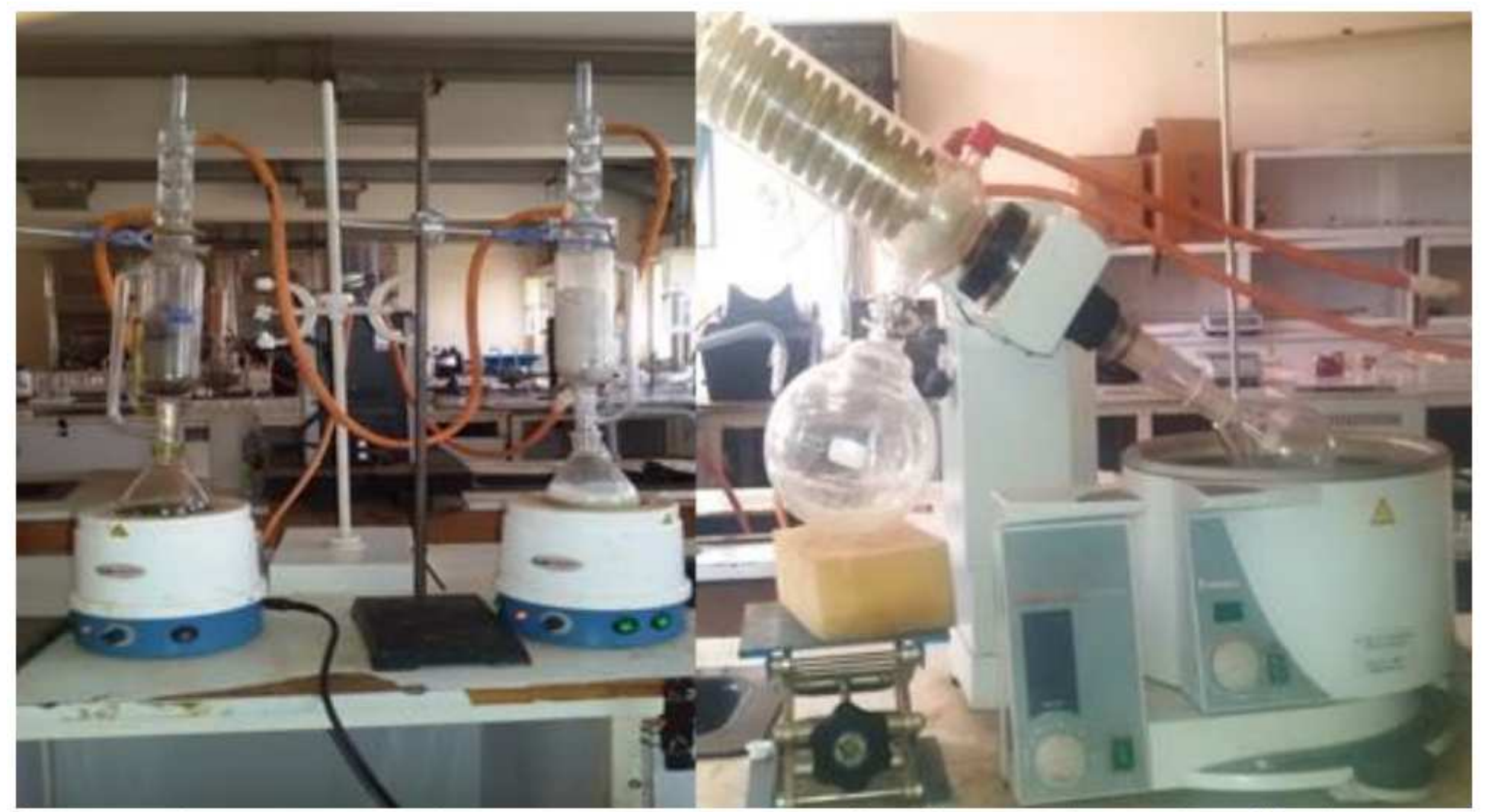

\section{Figure 3}

Soxlet apparatus and Rotary evaporator setup for oil extraction and purification

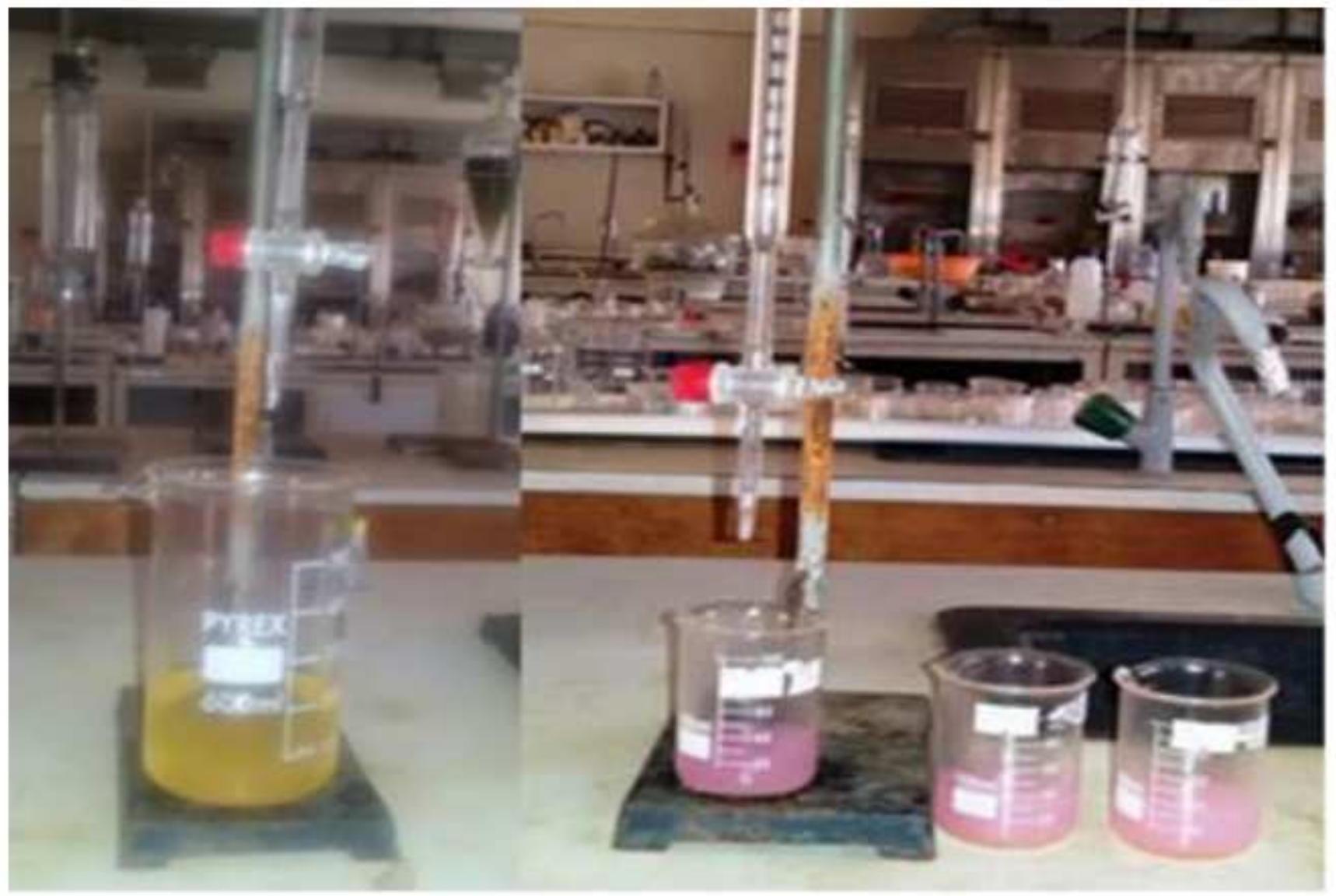


Figure 4

Determinations of acid value of mixed oil and biodiesel samples by titration method

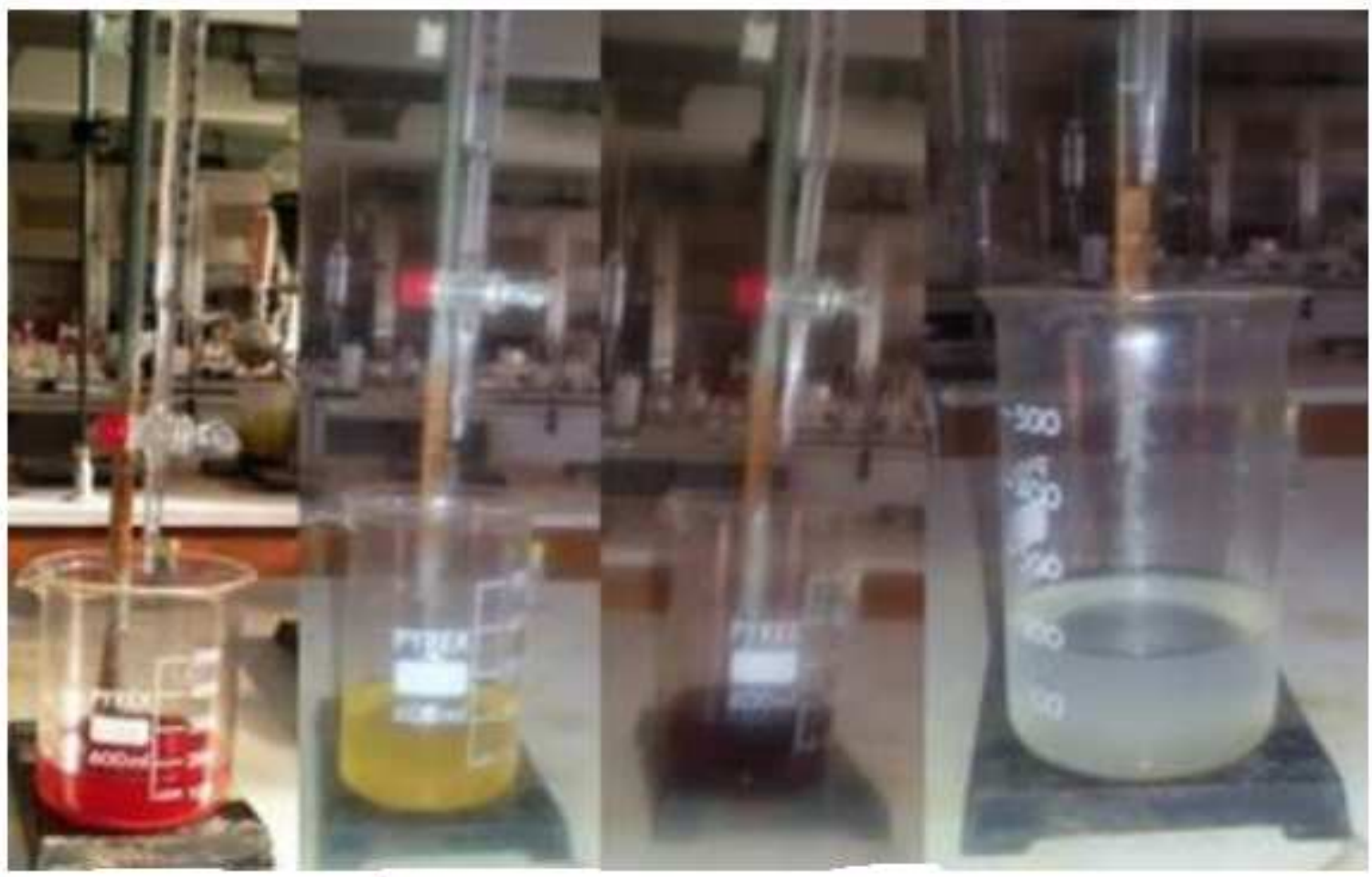

\section{Figure 5}

Determination of lodine value by titration method

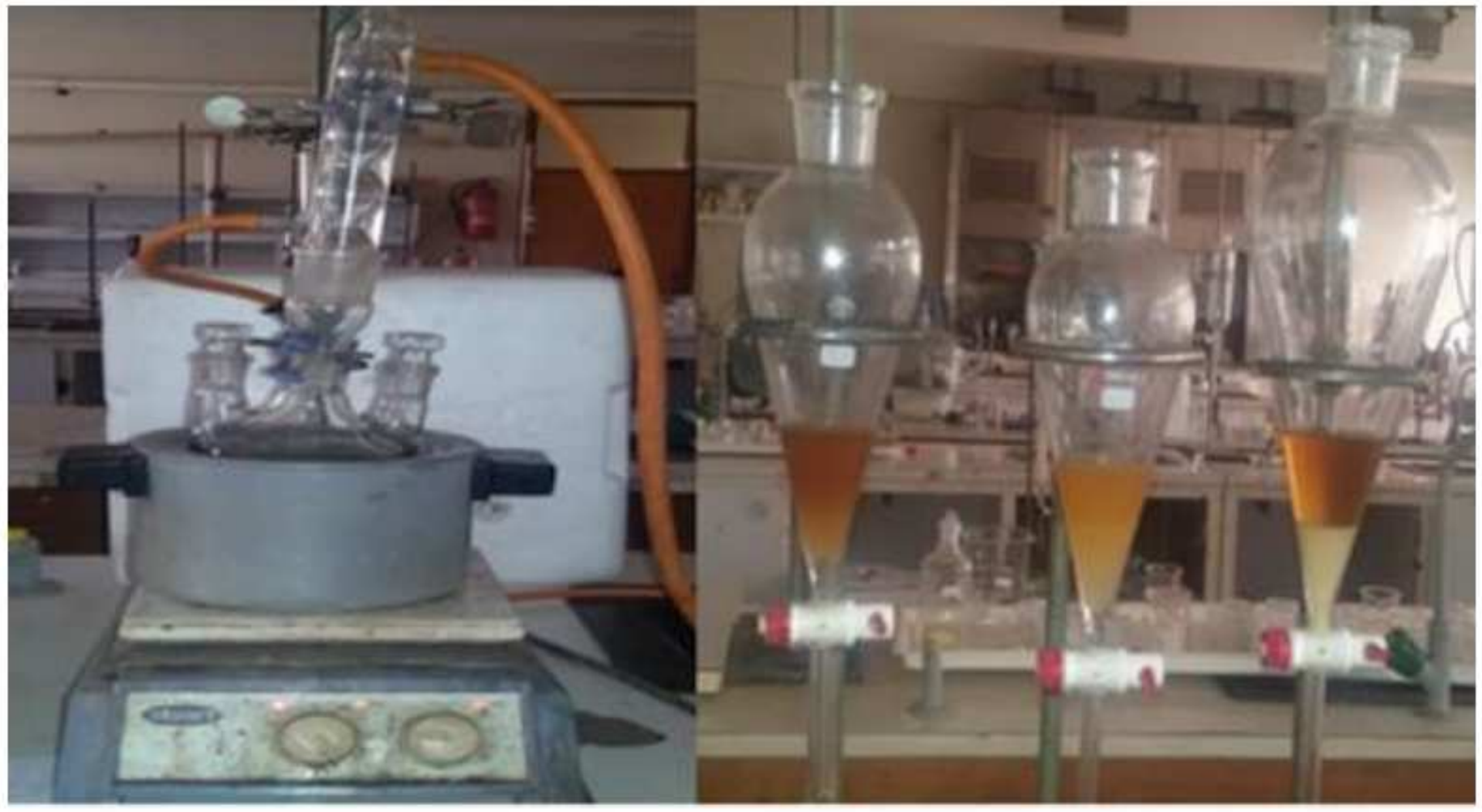


Figure 6

Mixed oil tranisterification and separation of resulting biodiesel

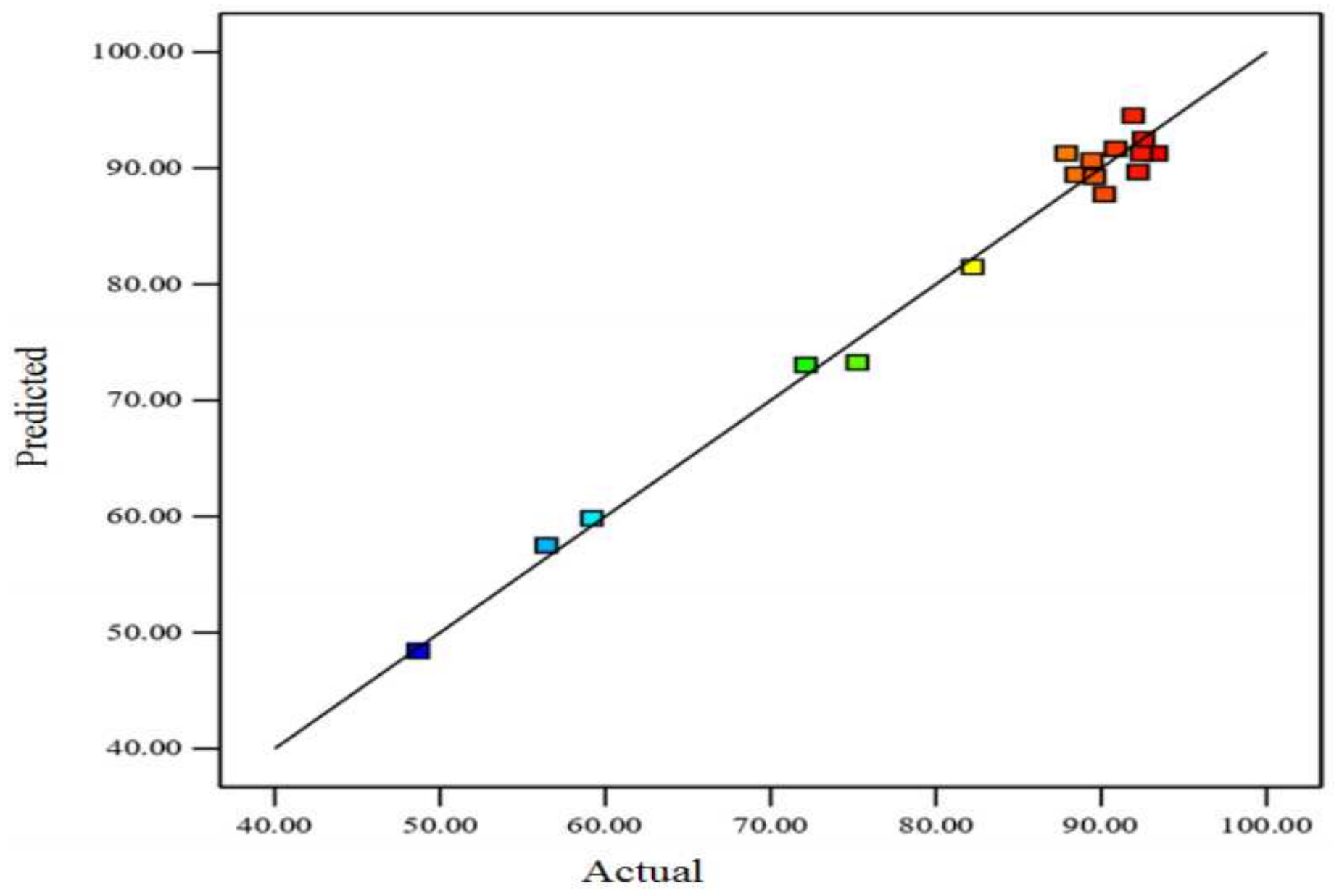

Figure 7

Comparison between actual and predicted value of biodiesel yield 


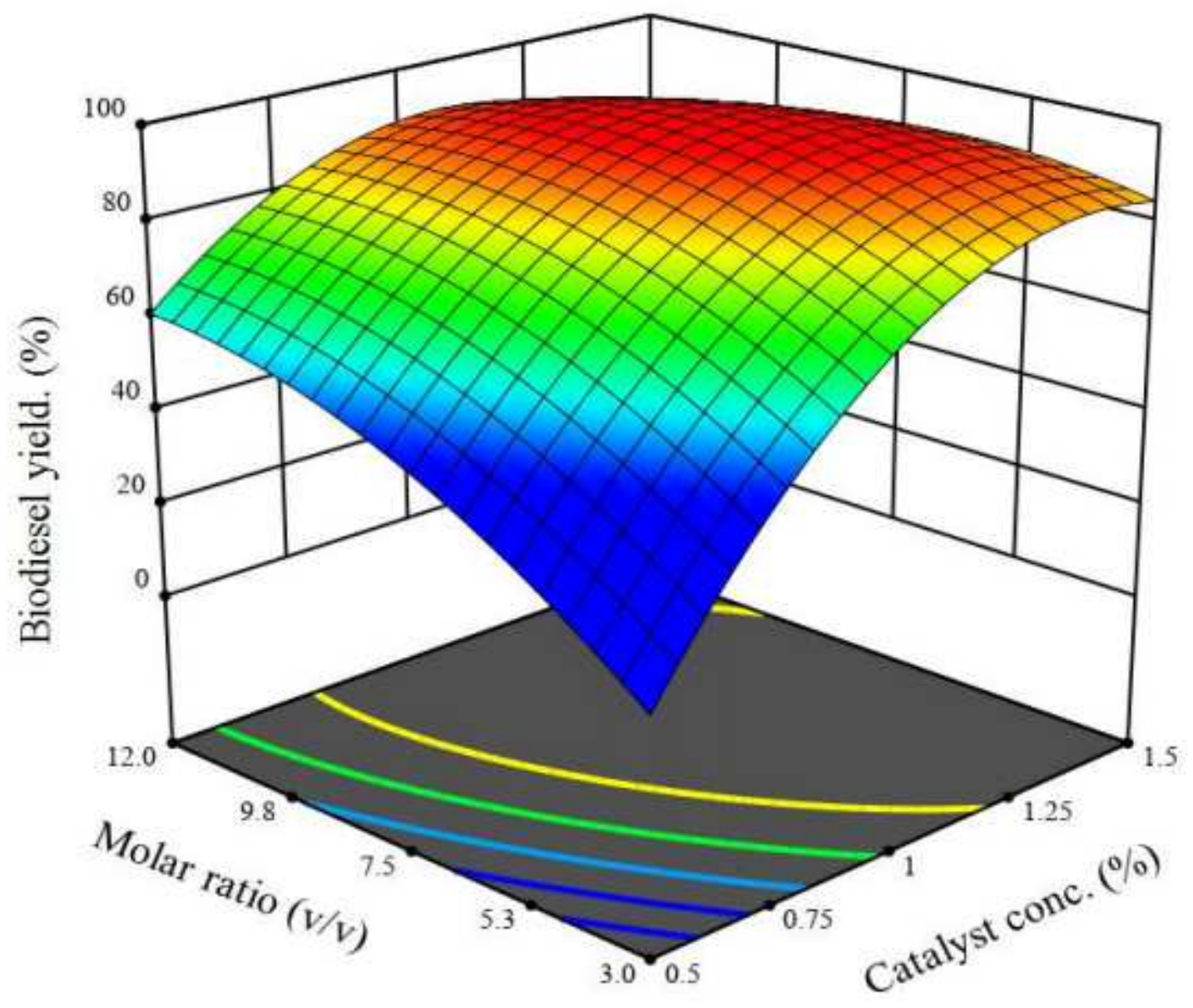

Figure 8

Effect of ethanol to oil molar ratio and catalyst concentration on yield of biodiesel at constant reaction temperature of $50 \mathrm{oC}$ 


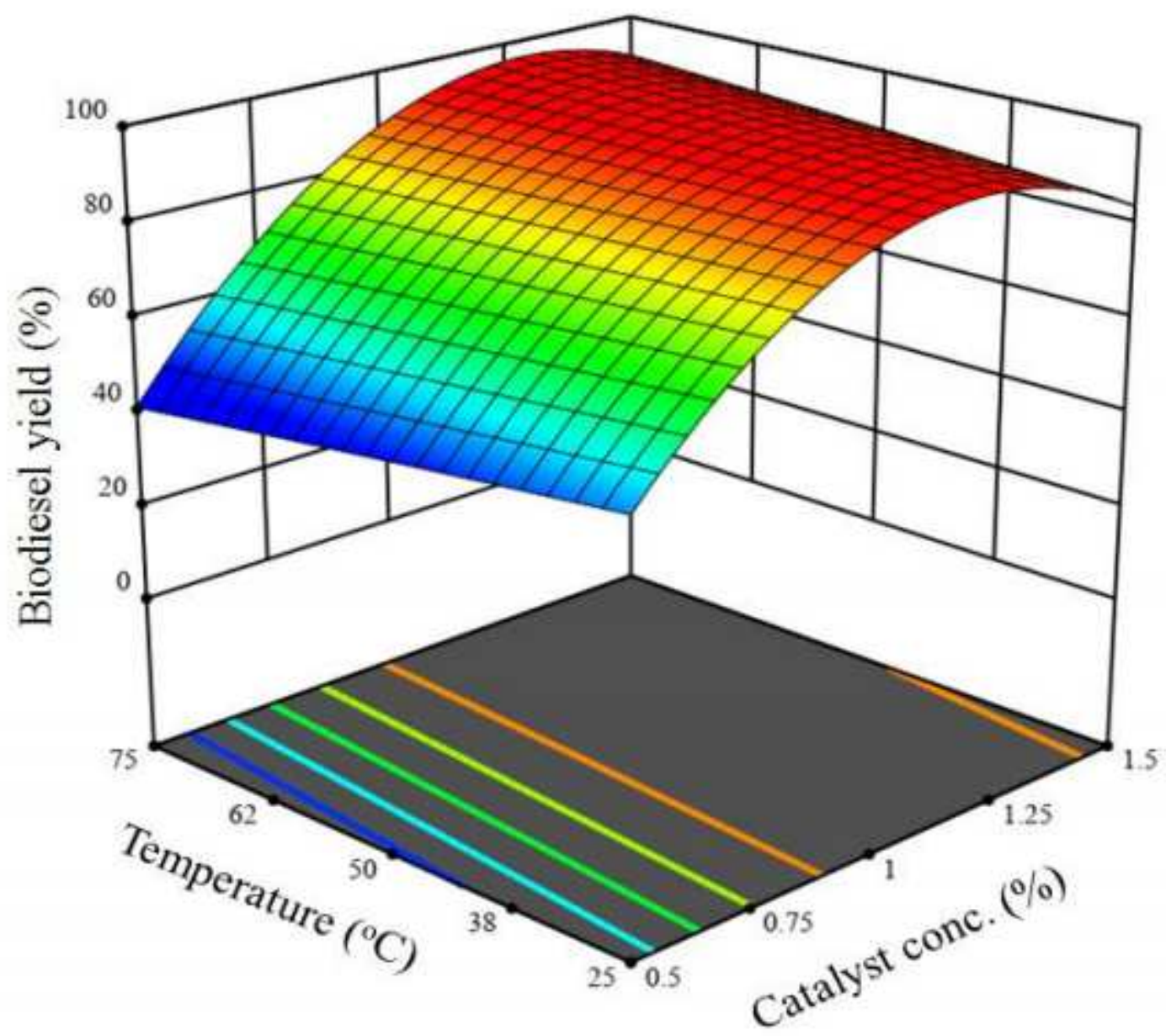

Figure 9

Effect of reaction temperature and catalyst concentration on yield of biodiesel at constant ethanol to oil molar ratio of 7.5:1 


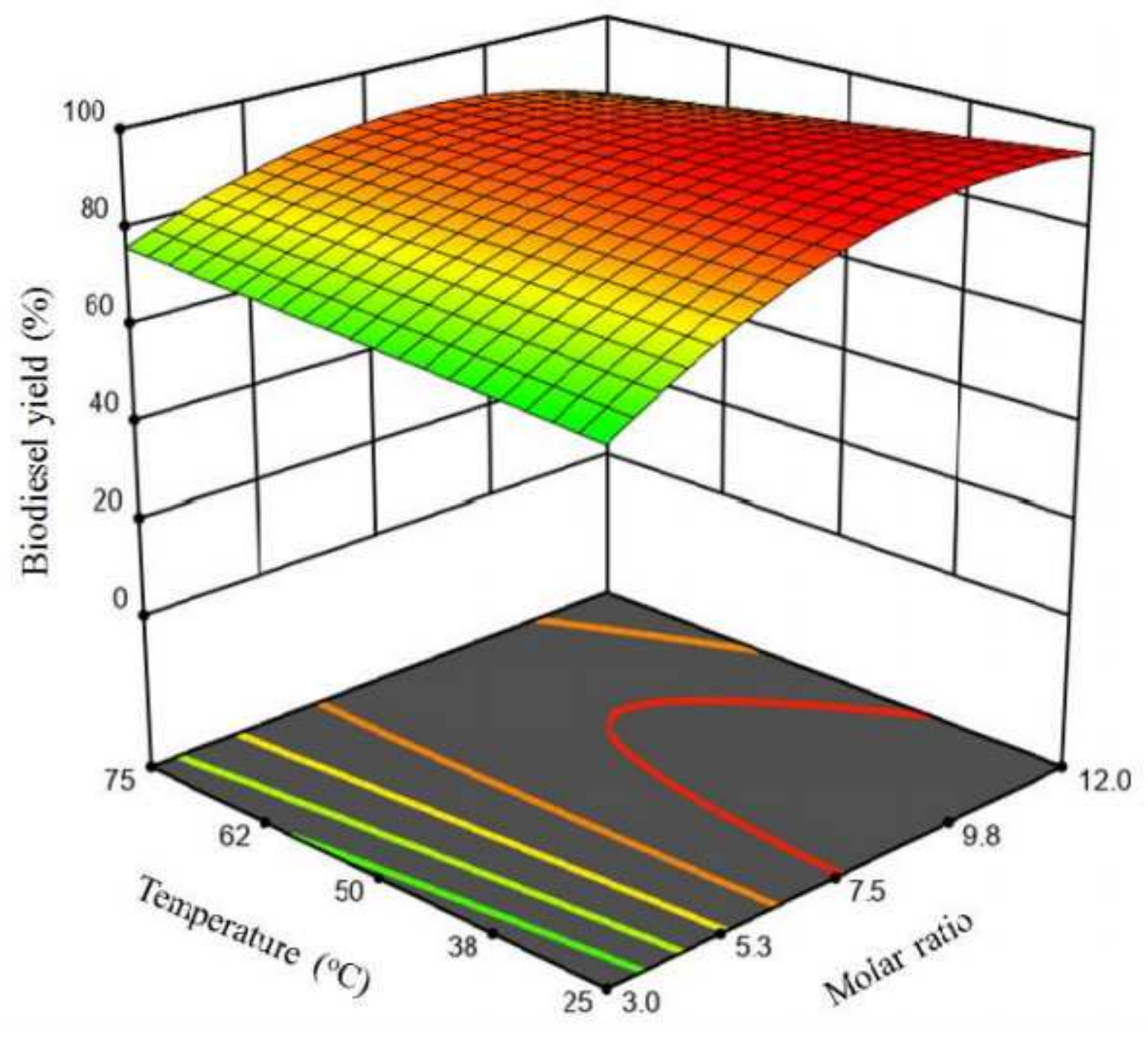

Figure 10

Effect of reaction temperature, ethanol to mixed oil molar ratio and their combined interaction on the yield of biodiesel at constant catalyst concentration of $1 \% \mathrm{wt}$. 